\title{
WestVirginiaUniversity
}

THE RESEARCH REPOSITORY @ WVU

West Virginia Agricultural and Forestry Experiment

Davis College of Agriculture, Natural Resources

Station Bulletins

And Design

$1-1-1970$

\section{Structural changes in the West Virginia fluid milk industry}

Robert M. Bragg

James H. Clarke

Follow this and additional works at: https://researchrepository.wvu.edu/ wv_agricultural_and_forestry_experiment_station_bulletins

\section{Digital Commons Citation}

Bragg, Robert M. and Clarke, James H., "Structural changes in the West Virginia fluid milk industry" (1970). West Virginia Agricultural and Forestry Experiment Station Bulletins. 588T.

https://researchrepository.wvu.edu/wv_agricultural_and_forestry_experiment_station_bulletins/692 @ WVU. It has been accepted for inclusion in West Virginia Agricultural and Forestry Experiment Station Bulletins by an authorized administrator of

The Research Repository @ WVU. For more information, please contact ian.harmon@mail.wvu.edu. 


\section{STRUCTURAL CHANGES \\ IN THE \\ WEST VIRGINIA \\ FLUID \\ MILK \\ INDUSTRY}

BULLETIN 588T

FEBRUARY 1970

WEST VIRGINIA UNIVERSITY

AGRICULTURAL EXPERIMENT STATION 
Blank Page in Original Bulletin 


\section{CONTENTS}

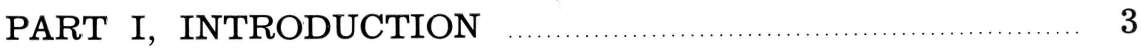

Industry Problems ….............................................. 3

Purpose and Objectives …........................................... 5

Questions to be Answered ......................................... 6

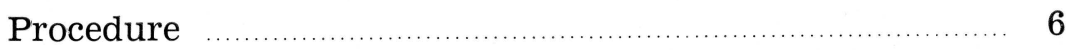

PART II, CHANGES IN THE MARKET STRUCTURE OF THE FLUID MILK INDUSTRY …

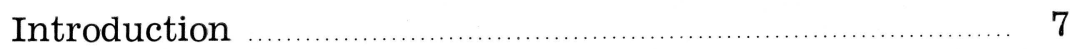

Characteristics of Sellers …....................................... 8

Merger Activity ........................................................ 19

Changes in the Method of Distribution …....................... 22

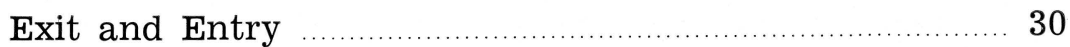

Institutional Environment in Which Changes Occurred . . 38

Changes in the Structure of the Buying Market ............... 43

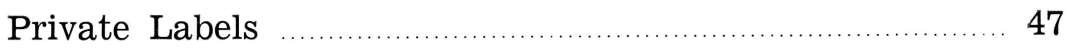

PART III, THE EFFECT OF THE CHANGING STRUCTURE ON MARKET CONDUCT AND PERFORMANCE …............ 51

The Effect of Change in Structure on Competitive Behavior …..................................... 52

Performance of the Fluid Milk Processing Industry ........ 54

Profit and Price Performance ...................................... 55

PART IV, SUMMARY, CONCLUSIONS,

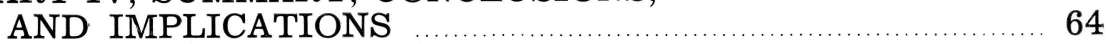

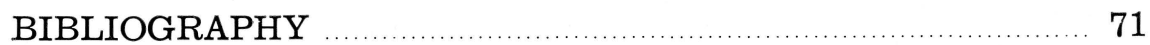

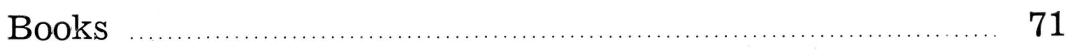

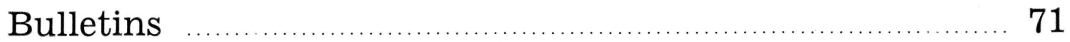

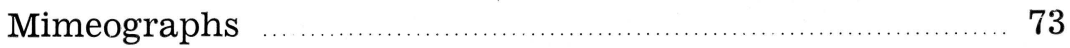

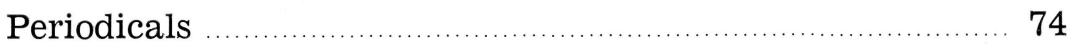

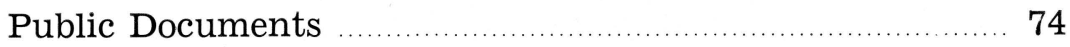

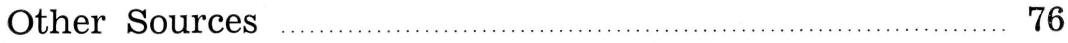




\section{THE AUTHORS}

Robert M. Bragg was formerly Graduate Research Assistant and James H. Clarke is Agricultural Economist.

\section{ACKNOWLEDGMENTS}

The authors express their appreciation to present and past personnel of the West Virginia fluid milk industry for their help in providing answers to questions. They are also indebted to Harold Amick of the West Virginia Department of Agriculture for providing lists of licensed milk plants and to the State Department of Health for information pertaining to health regulations of the fluid milk industry. Mrs. Mary Templeton and her staff gave assistance with tabulation of data and statistical analysis. They are also grateful to Dr. K. D. McIntosh, Dr. A. L. Barr, and Professor S. J. Weese for helpful suggestions made during the course of the study.

West Virginia University Agricultural Experiment Station College of Agriculture and Forestry

A. H. VanLandingham, Director Morgantown 


\section{Structural Changes in the West Virginia Fluid Milk Industry-1946-1967}

\section{ROBERT M. BRAGG and JAMES H. CLARKE}

\section{PART I \\ INTRODUCTION}

\section{Industry Problems}

The structure of the fluid milk industry has undergone considerable change since World War II. There has been a significant reduction in the number of plants and processors with an accompanying trend toward larger plants and increased concentration of both processing and ownership.

Several factors have contributed to the change in the industry's structure. Included are substantial changes in production and distribution technology, changes in the institutional structure, and substantial changes in the traditional customer purchase habits and distributional patterns.

The growth of a network of superhighways, greater efficiency in milk transportation and refrigeration equipment, and the development of bulk handling equipment for the farm, for hauling, and for processing plants have increased the distance milk can be transported in a marketable condition.

The growth of larger supermarkets during the period following World War II has had a marked influence on the number of processors that have been able to successfully compete for this business. Prior to World War II home delivered milk accounted for about 60 per cent of total sales. Retail prices at stores were usually the same as those for home-delivered milk. ${ }^{1}$ Home delivery as the major channel of milk distribution has been replaced until less than one-third of total sales are made in this manner."

${ }^{1}$ Federal Trade Commission, In the Matter of Beatrice Foods Company, A Corporation, Initial Decision, Docket No. 6653, March 2, 1964, p. 12.

${ }^{2}$ E. R. Baumer. "Home Delivery Revisited," Milk Distribution and Packaging - Trends in the Dairy Industry. University of Illinois, Department of Agricultural Economics Bulletin No. 13, (Urbana, Illinois: University of Illinois, 1967), p. 5. 
Concentration in the grocery retailing industry as well as in the fluid milk industry has resulted in the competitive elimination of many small and medium-volume processors. Today, most milk is retailed through stores and, of this, much is sold through regional or national chain stores. Some of the large corporate chains and voluntary and cooperative chains have initiated buying plans on a regional basis. This method creates the opportunity for large-volume buyers to bargain for substantial wholesale discounts.

Many processors have been affected by the introduction of private-label (the final seller's brand) brands of milk in the supermarkets. Often the processor finds it necessary to put in privatelabel containers in order to insure himself space for his own label in the same stores.

As a result of the rapidly growing volume of milk sold through stores, processing and distribution facilities have become more concentrated. The incentive to increase plant size was especially stimulated by the adoption of paper containers. The greater capacity of equipment adapted to paper containers gave large-volume wholesale processors a competitive advantage over small-volume processors because this innovation is associated with low cost for the large-scale operations relative to small-scale operations.

The institutional changes which have occurred in the post-World War II period, including the almost universal adoption by municipalities and states of the Grade A Model Code of the U.S. Public Health Service, establishment and expanding coverage of Federal milk marketing orders, and decisions by the Federal Trade Commission, have influenced the structure of the industry considerably.

Widespread acceptance of more uniform sanitary regulations has greatly diminished the artificial barrier to free movement of milk between cities and states. Federal milk marketing areas have also expanded, which usually reflects an increase in the sales areas of plants. Many small-volume processors, who were formerly not subject to such orders, found their costs increasing after the extension of the areas where milk marketing was regulated.

Although the number of plants in the industry continues to decline, total market shares of the large national firms remain stable. This circumstance was not necessarily noted in all markets, which is no doubt due, in part, to the legal constraints placed on these firms by the Clayton Act as administered by the Federal 
Trade Commission. It appears that large independent and regional chain firms, rather than national chains, are acquiring much of the business of the small-volume processors leaving the industry. ${ }^{3}$

The industry changes which have occurred since World War II have usually resulted in increased economic pressure on the smaller fluid milk firms, many of which have not been able to purchase the more expensive processing equipment and have not had the volume to justify the leasing of automatic paper packaging equipment. The result has been a decline in the number of small-volume processors. Many of these businesses have been acquired by larger companies. As a result of the various changes discussed above, there has been a consolidation of processing plants, even among the larger firms, in order to utilize the expensive types of automatic equipment more efficiently. Many of the smaller processing plants have been converted into distribution or sales branches.

\section{Purpose and Objectives}

The purpose of this study is to describe and analyze the structural changes which have taken place in the fluid milk industry in West Virginia and to appraise and evaluate the possible impact these changes have had on producers, handlers, and consumers.

The exploratory hypothesis of this study is that the structure of the fluid milk industry in West Virginia in 1967 was formed in part by certain fundamental changes in fluid milk processing and distribution. These structural changes are apparently rooted in certain market changes, especially in technological developments fostering large-volume operation and merchandising and in changes at the retail level.

The objectives of this study were:

1. To determine how and to what extent the structure and institutional framework of the fluid milk industry in West Virginia has changed during the post-World War II period.

2. To determine the factors associated with the changes in the structure, especially the roles of the changing structure of food retailing and recent technological changes in fluid milk processing and distribution.

3. To investigate the effects of the change in structure on competitive behavior and industry performance.

${ }^{3}$ Charles E. French, Indiana Independent Fluid Milk Companies, Indiana Agricultural Experiment Station, Research Report No. 115, (Lafayette, Indiana, : Purdue University, 1964), pp. 2-3. 
4. To determine the consequent effect of such changes upon producer and consumer prices.

\section{Questions to be Answered}

Answers to the following questions were sought to fulfill the objectives stated above:

1. What changes have occurred in the physical volume and numbers of both buyers and sellers of processed fluid milk in West Virginia?

2. What is the nature and extent of market power possessed by both buyers and sellers at the several levels of trade within the industry?

3. What were the factors that influenced firms to go out of business?

4. What changes have occurred in the postwar institutional framework and what has been the impact of these changes on the structure of the industry?

5. What forms of competitive behavior have resulted from the change in structure?

6. What has been the effect of the change in market structure on industry profits and on the adoption of new technology?

7. What have been the general effects of the change in structure on producers and consumers in terms of prices received and paid?

\section{Procedure}

In order to gather the necessary information to answer the questions raised and to test the exploratory hypothesis, the following procedures were undertaken.

COLLECTION OF PRIMARY DATA. The field survey method was used to obtain data on individual fluid milk plants throughout the State.

Lists of licensed fluid milk plants in West Virginia, 1946 to 1967, were obtained from the West Virginia Department of Agriculture. These lists were used in compiling information on plants in operation at the time the field survey was made and on plants that had left the industry during this period. It was determined that 30 plants were in operation as of December 31, 1967, and that 85 plants had left the industry and only 58 plants entered the industry from 1946 to December 31, 1967.

Representatives of all of the plants in operation at the time of the survey were interviewed. An effort to contact as many of 
the "former" operators as possible resulted in locating only 35 representatives. Only 30 questionnaires were completed on plants in this category.

In addition to the interviews with representatives of fluid milk plants, information about health regulations was obtained through personal interviews with officials of the State Health Department. Also, while the field survey of plant operators was being conducted, approximately 200 retail grocery stores, chain and non-chain, were visited by the authors to collect price data on private-label and processor-label milk.

SOURCES OF SECONDARY DATA. A substantial part of the data used in this study came from secondary sources. These included trade journals, United States Department of Agriculture monthly and annual reports, various experiment station reports, and government investigations of business firm activities. These secondary data were used to supplement data obtained from the questionnaires and to provide information for comparisons between West Virginia markets and other markets throughout the United States.

\section{PART II}

\section{CHANGES IN THE MARKET STRUCTURE OF THE FLUID MILK INDUSTRY}

\section{Introduction}

The purpose of this study was to investigate some of the changes in the structure of the fluid milk industry in West Virginia and the consequent effect of such changes upon the industry as measured by its influence on consumer and producer prices. Other measures of performance were not available for analysis from the data available.

Since the basic assumption of this study is that market structure is a strategic variable determining firm conduct and performance, this part examines the existing structure and the changes which have taken place in it during the preceding 22 years. ${ }^{1}$ In addition recent technical studies of market structure made by the National Commission on Food Marketing were examined. Studies of Federal milk market regulation and of public health regulation also were reviewed.

${ }^{1}$ A comprehensive review of selected studies which have emphasized the theoretical relationship between market structure and performance can be found in an unpublished master's thesis by Robert M. Bragg, Structural Changes in the West Virginia Fluid Milk Industry, 1946 to 1967, West Virginia University, January, 1969, Chapter II. 


\section{Characteristics of Sellers}

NUMBER. The number of fluid milk processing plants in the United States has sharply declined since 1948. According to estimates prepared by the United States Department of Agriculture there were approximately 19,711 fluid milk processing plants in the United States that year. By January, 1965, the number of plants had decreased nearly 72 per cent or to approximately $5,597 .^{2}$

Most of the decrease in plant numbers was accounted for by exit from the industry of small, on-the-farm operations or producer-processors. Whereas in 1948 there were approximately 11,319 producer-processors, by January, 1965 the number had declined 85 per cent to a total of approximately 1,677. During the same period, the number of plants operated by processor-distributors decreased 53 per cent or from 8,392 to $3,920 .^{3}$

The trend has been somewhat similar for the fluid milk processing industry in West Virginia except the number of plants has been declining for a shorter period (Figure 1). The total number of licensed plants increased from 57 to 73 during the period 1946 to 1954 (Figure 1). During this period the number of processor-distributors increased by 12 and producer-processors by four-net increases of 23 per cent and 100 per cent, respectively.

The total number of fluid milk plants declined by 59 per cent between 1954 and December, 1967. Whereas in 1954 there were 73 plants, by December, 1967 only 30 remained and eight of these were producer-processors. The net decline in the total number of plants was accounted for solely by exit from the industry of processor-distributors. During the period 1954 to December, 1967 processor-distributors decreased from 65 to 22 while the net change in the number of producer-processors was zero (Table 1). An average of 3.3 plants per year have left the industry since 1954 .

In West Virginia the decline in the number of processor-distributors followed the national trend during the period under consideration. However, it should be pointed out that while the number of producer-processors declined 85 per cent nationally between 1948 and 1965, the number in West Virginia actually increased 80 per cent during the same period. An explanation of the ability of producer-processors to continue operations will be presented later in this part.

${ }^{2}$ National Commission on Food Marketing, Organization and Competition in the Dairy Industry, Technical Study No. 3, (Washington, D. C., U.S. Government Printing Office, 1966), p. ${ }^{64}$ Ibid. 


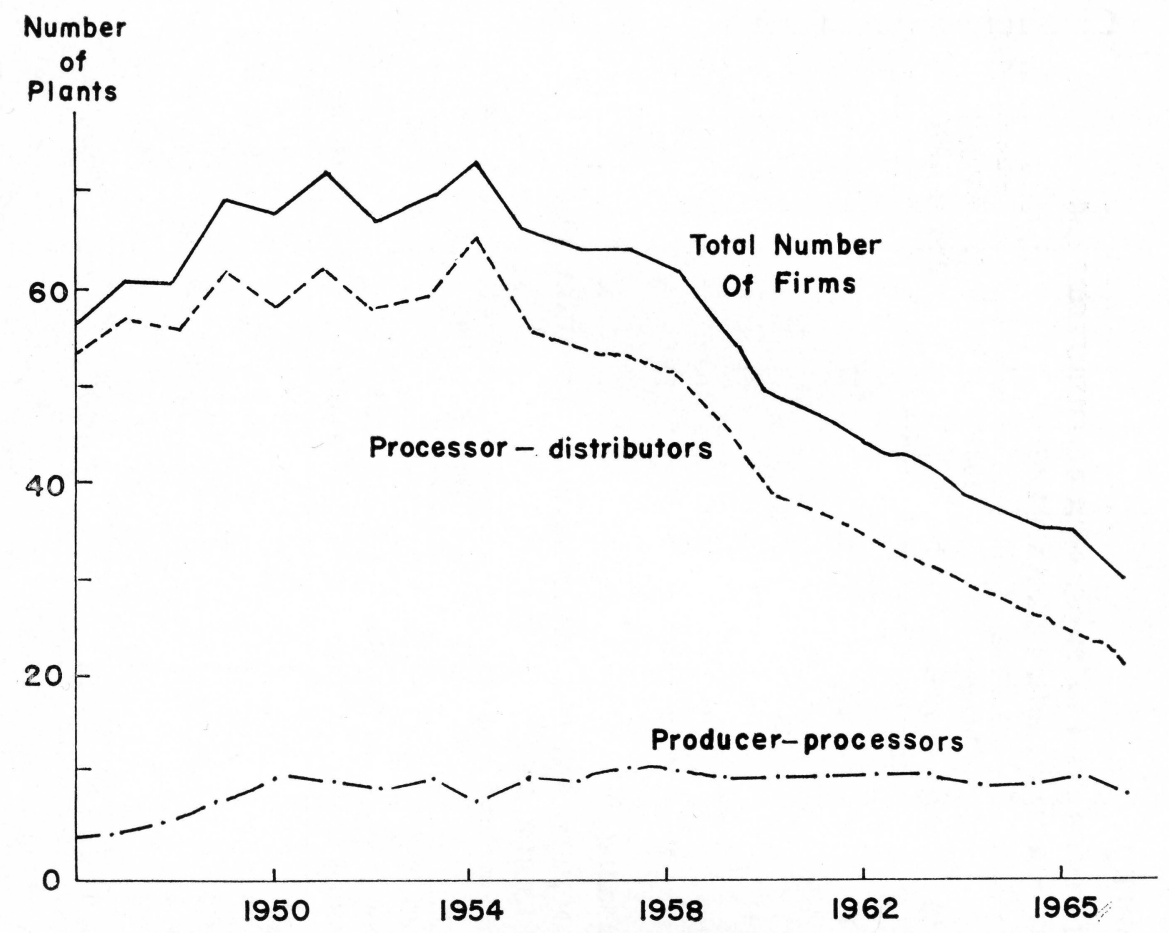

FIGURE 1. Estimated number (as of December 31) of fluid milk processing plants in West Virginia, 1946-6\%.

SIZE. For this analysis plants were grouped by the following size categories:

Annual volume per plant in pounds

$$
\begin{aligned}
& \text { Less than } 1,000,000 \\
& 1,000,000 \text { to } 4,999,999 \\
& 5,000,000 \text { to } 9,999,999 \\
& 10,000,000 \text { to } 19,999,999 \\
& 20,000,000 \text { and over }
\end{aligned}
$$

The above categories allow comparison between 1967 plant output and 1956 output. Comparative data for 1956 was the only other year for which individual plant volume could be obtained. Producer-processors were omitted since volume data were not available for comparison.

The number of plants in each category, except plants processing over 20 million pounds a year, declined during the period 1956 to December, 1967 (Table 2). The number of plants with 
TABLE 1

NUMBER of FLUID MILK PROCESSING PLANTS OPERATED by PROCESSOR-DISTRIBUTORS and PRODUCER-PROCESSORS, WEST VIRGINIA, 1946, 1954, AND $1967^{\mathrm{a}}$

\begin{tabular}{|c|c|c|c|c|c|c|c|c|}
\hline \multirow{2}{*}{$\begin{array}{c}\text { Type of } \\
\text { Operation }\end{array}$} & \multicolumn{2}{|c|}{1946} & \multicolumn{2}{|c|}{1954} & $\%$ Change & \multicolumn{2}{|c|}{1967} & \multirow{2}{*}{$\begin{array}{c}\% \text { Change } \\
1954 \text { to } 1967\end{array}$} \\
\hline & No. & $\%$ & No. & $\%$ & 1946 to 1954 & No. & $\%$ & \\
\hline $\begin{array}{l}\text { Processer- } \\
\text { distributor }\end{array}$ & 53 & 93 & 65 & 89 & +23 & 22 & 73 & -66 \\
\hline $\begin{array}{l}\text { Producer- } \\
\text { processor }\end{array}$ & 4 & 7 & 8 & 11 & +100 & 8 & 27 & 0 \\
\hline
\end{tabular}

${ }^{\mathrm{a}} \mathrm{As}$ of December 31

TABLE 2

DISTRIBUTION of FLUID MILK PLANTS ${ }^{a}$ by ESTIMATED ANNUAL VOLUME, WEST VIRGINIA, 1956 AND DECEMBER, 1967

\begin{tabular}{|c|c|c|c|c|c|c|}
\hline \multirow[b]{2}{*}{$\begin{array}{l}\text { Plant Size } \\
\text { Annual Volume } \\
\quad \text { (Million lb.) }\end{array}$} & \multirow[b]{2}{*}{ Number } & \multicolumn{2}{|c|}{1956} & \multicolumn{3}{|c|}{ December, 1967} \\
\hline & & $\begin{array}{c}\% \\
\text { of } \\
\text { Plants }\end{array}$ & $\begin{array}{c}\% \\
\text { of } \\
\text { Volume }\end{array}$ & Number & $\begin{array}{c}\% \\
\text { of } \\
\text { Plants }\end{array}$ & $\begin{array}{c}\% \\
\text { of } \\
\text { Volume }\end{array}$ \\
\hline Less than 1.0 & 21 & 36.2 & 3.9 & 1 & 4.5 & 0.3 \\
\hline 1.0 to 4.9 & 19 & 32.8 & 18.8 & 8 & 36.4 & 9.6 \\
\hline 5.0 to 9.9 & 8 & 13.8 & 19.8 & 4 & 18.2 & 10.6 \\
\hline 20.0 and over & 1 & 1.7 & 12.0 & 4 & 18.2 & 53.2 \\
\hline TOTAL & 58 & 100.0 & 100.0 & 22 & 100.0 & 100.0 \\
\hline
\end{tabular}

aData do not include producer-processors 
annual volumes under one million pounds decreased sharply, from 21 to one, while plants in the three intermediate size groups declined but not as rapidly as those in the smallest size group. Plants processing over 20 million pounds of fluid milk annually increased from one to four during the same period (Table 2).

Accompanying the overall decrease in the number of fluid milk plants in most size groups was an increase in the average volume processed in those remaining. Although the total volume of milk processed increased only 3.1 per cent, average plant volume has increased 171.8 per cent in the last 12 years (Table 3 ).

Large plants accounted for an increasingly larger share of the total annual volume of fluid milk processed in the State. This in turn brought a substantial change in the size distribution of all plants.

Whereas in 1956 those plants processing less than one million pounds annually processed approximately 3.9 per cent of the total volume, by 1967 plants in this category were processing only 0.3 per cent. Likewise, in plants processing one million to 4.9 million and five million to 9.9 million pounds, respectively, the per cent of total volume processed decreased from 38.6 per cent to only 20.2 per cent (Table 2 ).

The data presented in Table 2 indicate that the plants with annual volumes of 10 million pounds or more increased their share of the total volume from 57.5 per cent to 79.5 per cent between 1956 and 1967. Although plants in each size group increased in volume per plant, those in the four smallest groups each and collectively declined in the share of the total volume processed.

TABLE 3

CHANGES in VOLUME OF FLUID MILK PROCESSED ANNUALLY, a NUMBER of PLANTS, and AVERAGE OUTPUT per PLANT, WEST VIRGINIA, 1956-67

\begin{tabular}{|c|c|c|c|}
\hline \multirow[b]{2}{*}{ Unit } & \multicolumn{2}{|c|}{ Year } & \multirow{2}{*}{$\begin{array}{c}1967 \text { as } \\
\text { Per Cent } \\
\text { of } 1956\end{array}$} \\
\hline & $1955-1956^{b}$ & 1967 & \\
\hline $\begin{array}{l}\text { Total Volume Processed } \\
\text { in the State (lb.) }\end{array}$ & $273,060,650$ & $281,416,122$ & 103.1 \\
\hline Number of Plants & 58 & 22 & 37.9 \\
\hline $\begin{array}{l}\text { Average Volume } \\
\text { per Plant (lb.) }\end{array}$ & $4,707,942$ & $12,796,187$ & 271.8 \\
\hline
\end{tabular}

${ }^{a}$ Excludes volume processed by producer-processors both years

bSource: Report of the West Virginia Governor's Milk Commission, February 1, 1957, 
Plants in the largest size group had grown to the extent that they were processing 53.2 per cent of the total annual volume. It should be re-emphasized that, in 1956, the only plant in the largest size category processed 12.0 per cent of the total volume, but in the relatively short span of 12 years plants in this size group grew to the point where they were processing well over 50 per cent of the fluid milk in the State (Table 2). Furthermore, it should be remembered that plants in the largest size category increased their share of the total volume in spite of the fact that the total annual volume of fluid milk processed within the State increased only 3.1 per cent between 1956 and December, 1967 (Table 3).

Technological developments, especially the introduction of the paper package; the high-temperature, short-time pasteurizer; larger and more efficient refrigeration equipment; and better highways were primarily responsible for the decline in the number of small fluid milk plants and the increase in large-scale plants.

CHANGES IN MARKET CONCENTRATION. The preceding data on size and number of plants indicate that the fluid milk processing industry in West Virginia has become more concentrated since 1954. Concentration has been defined as-"the extent to which output of a product is controlled by the largest firms."

One way to measure concentration is to divide the volume of fluid milk processed by a firm or group of firms by the total volume processed in a given market or area. This measure is known as the concentration ratio. The ratio may be used to measure the extent of oligopoly or to measure the relative size of the largest units, regardless of the degree of oligopoly. ${ }^{5}$

The concentration ratios for the four, eight, 12, and 16 largest fluid milk firms in West Virginia were computed for 1956 and 1967 (Table 4). Only processor-distributors were considered because (1) the decline in the total number of plants between the two periods was predominately influenced by a decline in the number of processor-distributors and (2) producer-processors have had an insignificant impact upon the industry because their share of the market was very small and has been for a number of years.

${ }^{4}$ Ibia., p. 67.

${ }^{5}$ M. A. Adelman. "The Measurement of Industrial Concentration," Readings in Industrial organization and Public Policy, (Homewood, Illinois: Richard D. Irwin, Inc., 1958), p. 6. 
TABLE 4

CONCENTRATION RATIOS for FOUR, EIGHT, TWELVE and SIXTEEN LARGEST FLUID MILK FIRMS, a,b WEST VIRGINIA, 1956 AND 1967

\begin{tabular}{|c|c|c|c|c|c|c|c|}
\hline \multirow{2}{*}{ Year } & \multirow{2}{*}{$\begin{array}{l}\text { Number } \\
\text { of } \\
\text { Plants }\end{array}$} & \multirow{2}{*}{$\begin{array}{l}\text { Number } \\
\text { of } \\
\text { Firms }\end{array}$} & \multirow{2}{*}{$\begin{array}{c}\text { Estimated } \\
\text { Annual } \\
\text { Volume } \\
\text { (lb.) }\end{array}$} & \multicolumn{3}{|c|}{$\begin{array}{l}\text { Concentration Ratio: Percentage of Total } \\
\text { Annual Output in Pounds Accounted for by: }\end{array}$} & \multirow{2}{*}{$\begin{array}{c}\text { Herfindahl } \\
\text { Index }^{6}\end{array}$} \\
\hline & & & & $\begin{array}{l}4 \text { Largest } \\
\text { Firms }\end{array}$ & $\begin{array}{lc}8 \text { Largest } & 12 \text { Largest } \\
\text { Firms } & \text { Firms }\end{array}$ & $\begin{array}{l}16 \text { Largest } \\
\text { Firms }\end{array}$ & \\
\hline 1956 & 58 & 56 & $273,060,650^{d}$ & 39.8 & 68.9 & 77.3 & .058402 \\
\hline 1967 & 22 & 20 & $281,516,122$ & 61.7 & 91.8 & 97.5 & .130216 \\
\hline
\end{tabular}


The measures (concentration ratios in Table 4) reveal that the shares of the largest four, eight, 12, and 16 firms have increased substantially between 1956 and 1967. For instance, in 1956 the four largest firms' share of the total volume of fluid milk processed in the State was approximately 40 per cent. By 1967 their share had increased to nearly 62 per cent (Table 4 ). In other words, the share of the volume processed by the four largest firms increased 55 per cent during the peroid under consideration. As of December, 1967 the four largest firms included two independent corporations and two national firms. Together they operated six plants in the State.

The share of the eight, 12, and 16 largest firms increased between 1956 and 1967 also but not as much as did the share of the largest four (Table 4). There has been a 45.4 per cent increase in the share of volume processed by the largest eight firms, a 33.2 per cent increase in the largest 12 firms' share, and a 25.1 per cent increase in the share of the volume processed by the largest 16 firms.

Another measure used to determine whether or not shares in a given market have increased is the Orris Herfindahl concentration measure. The Herfindahl index is calculated by computing the share of each firm in the market and squaring that number. These squared numbers are summed for all firms in the market. This measure represents the extent of concentration throughout the industry size distribution. ${ }^{6}$ If all of the firms had an equal share of the volume processed, the index would be equal to the reciprocal of the number of firms; or if only one firm constituted the industry, the value of the index would be unity.

The index was computed for the fluid milk processing industry in West Virginia for 1956 and 1967 and increased from 0.06 to 0.13 which indicated that concentration in fluid milk processing within the State has increased considerably (Table 4).

Measurement of market concentration requires that a definition of the relevant market be specified. In the preceding discussion on concentration all the calculations were based on the firms' share of fluid milk processed in plants located in West Virginia. The entrance of milk processed outside West Virginia will obviously affect competition and weaken the concentration ratios when computed on the basis of in-area sales rather than on the volume of milk processed within the State's boundaries.

${ }^{6}$ Padberg and Clarke, op. cit., pp. 27-28. 
A four-way classification system has been developed for use in measuring the concentration and determining the degree of competition in an industry. The four classifications are:

1. Highly concentrated oligopoly: the top four firms control from 75 to 100 per cent of the total industry production.

2. Moderately concentrated oligopoly: the top four firms control from 50 to 75 per cent of total industry production.

3. Slightly concentrated oligopoly: the top four firms control from 25 to 50 per cent of total industry production.

4. Atomistically competitive: the top four firms control less than 25 per cent of total industry production. ${ }^{7}$

Assuming this system applies to the fluid milk processing industry in West Virginia and outside milk is not considered, the industry has moved between 1956 and 1967 from group three, or a slightly concentrated oligopoly, to group two, or a moderately concentrated oligopoly. This type of structure creates a favorable environment for development of price leadership even when the leading firm makes no conscious effort to take advantage of its dominant position within the market.

From the evidence presented in this section, it is apparent that a larger share of total volume of fluid milk processed in West Virginia was controlled in 1967 by fewer and larger firms than was controlled by the same number of firms in 1956. Thus, the degree of concentration was increased.

The preceding discussion on market shares or concentration ratios has generally been in terms of fluid milk processed within West Virginia and did not include milk processed outside the State and shipped in for sale. Outside milk was excluded for the measurement of concentration on a state-wide basis primarily because adequate information could not be obtained. When smaller geographic areas were considered, i.e., Federal order market areas, more accurate measurement on market shares on in-area sales could be obtained.

The share of packaged fluid milk sales by the four largest handlers in Federal milk marketing order areas covering portions of West Virginia has increased in most cases since 1956 (Table 5). It appeared that the four largest firms in the Appalachian Order Area had a smaller share of the market in 1965 than they had in 1956; however, this was the result of a merger of order areas.

${ }^{7}$ Bain, Industrial organization, op. cit., pp. 110-124. 
TABLE 5

NUMBER of HANDLERS and SALES Of FOUR LARGEST HANDLERS OPERATING POOL PLANTS UNDER FEDERAL MILK MARKETING ORDERS, ${ }^{\circ}$ by MARKETING AREA, WEST VIRGINIA, MARCH 1956 AND DECEMBER 1965

\begin{tabular}{|c|c|c|c|c|c|c|}
\hline \multirow{3}{*}{$\begin{array}{l}\text { Market } \\
\text { and } \\
\text { Year }\end{array}$} & \multirow{2}{*}{\multicolumn{2}{|c|}{$\begin{array}{l}\text { Number of handlers } \\
\text { distributing packaged } \\
\text { milk on routes in this } \\
\text { marketing area from- }\end{array}$}} & \multicolumn{2}{|c|}{$\begin{array}{l}\text { Total sales of packaged fluid milk on } \\
\text { routes by the four largest handlers as } \\
\text { percentage of such sales of all pool plants in- }\end{array}$} & \multirow{3}{*}{$\begin{array}{l}\text { As percent- } \\
\text { age of their } \\
\text { sales in } 1962\end{array}$} & \multirow{3}{*}{$\begin{array}{l}\text { Sales of packaged fluid } \\
\text { milk on routes in the } \\
\text { marketing area by the } \\
\text { four largest handlers } \\
\text { as percentage of total } \\
\text { sales in the marketing } \\
\text { area by all types of } \\
\text { handlers }^{\mathrm{c}}\end{array}$} \\
\hline & & & \multirow{2}{*}{$\begin{array}{l}\text { Market area } \\
\text { as defined } \\
\text { at that } \\
\text { time }(\%)\end{array}$} & \multirow[t]{2}{*}{$\begin{array}{l}\text { Market area } \\
\text { as defined } \\
\text { in } 1967(\%)\end{array}$} & & \\
\hline & Pool plants & All plants & & & & \\
\hline \multicolumn{7}{|l|}{ Tri-State } \\
\hline March 1956 & 30 & 38 & 41.8 & 41.8 & 68.0 & 36.3 \\
\hline December 1965 & 24 & $\mathrm{NA}^{\mathrm{e}}$ & 59.9 & 62.5 & 170.0 & 55.0 \\
\hline \multicolumn{7}{|l|}{ Wheeling } \\
\hline March 1956 & 31 & 61 & 43.9 & 43.9 & 81.9 & 38.2 \\
\hline December 1965 & 15 & 34 & 68.8 & 68.8 & 145.6 & 54.7 \\
\hline \multicolumn{7}{|l|}{ Clarksburg } \\
\hline March 1956 & 12 & 57 & 88.3 & 88.3 & 76.7 & 71.2 \\
\hline December 1965 & 5 & 16 & $D^{f}$ & $D^{p}$ & 108.7 & 83.0 \\
\hline \multicolumn{7}{|l|}{ Appalachian ${ }^{d}$} \\
\hline March 1956 & 7 & 13 & 97.4 & $\mathrm{NA}^{\mathrm{e}}$ & 67.2 & 86.9 \\
\hline December 1965 & 9 & 16 & 81.6 & 81.6 & 116.0 & 77.8 \\
\hline
\end{tabular}

a Market order areas not confined to geographic areas in West Virginia

${ }^{b}$ Largest in terms of sales of the area

dDefinition of the marketing area was changed 3/1/61 with merger of Appalachian and Bluefield marketing orders

eNA - Data not available

${ }^{\mathrm{D}} \mathrm{D}$ - Data withheld to avoid disclosure of operations of individual firms Source : Compiled from Alden C. Manchester, Fluid Milk Markets - Numbers of Handlers and Market Shares 1950-65, Economic Research
sorvice, Statistical Bulletin No. 428 (Washington: U. S. Government Printing Office, June 1968) pp. 12-15 
Paralleling the national trend, the four largest handlers in West Virginia had a smaller share of total sales in the larger markets than in the smaller markets. For example, the market share of the four largest pool handlers ranged from 81.6 per cent in the Appalachian market to 59.9 per cent in the Tri-State market, which was the largest (Table 5).

OWNERSHIP CHARACTERISTICS. Of the 30 fluid milk plants still in operation in December, 1967, three were partnerships, three were operated by farmer cooperatives, eight were local proprietary single-plant firms, and 16, or 53.3 per cent, of the plants were owned by profit-type corporations (Table 6). These profit-type corporations accounted for 89.8 per cent of the total volume of milk processed in the State in 1967. Furthermore, single-unit corporations processed a little over twice as much milk as did the muti-unit corporations operating within the State (Figure 2). Farmer-owned cooperatives, local proprietary owners and partnerships, collectively comprising 46.7 per cent of the firms, processed only 10.2 per cent of the 1967 volume (Figure 2).

The per cent of the total number of firms accounted for by firms of various types in 1946 and 1955 is shown in Figure 3. Unfortunately, no data on the volume of milk processed by types of firms for 1946 and 1955 were available for comparison.

The majority of the firms processing less than one million pounds of fluid milk in 1967 were producer-processors. By type of ownership, four out of five of the single proprietary firms and all of the partnerships were producer-processors. Thirteen of the 17 plants in the two smallest size categories were proprietorships, partnerships, or cooperatives. Eleven out of the 13 firms processing over five million pounds in 1967 were profit-type corporations (Table 7). All of the plants in the largest size category were

TABLE 6

FLUID MILK PLANTS bY TYPE Of FIRM AND PER CENT Of ANNUAL VOLUME, WEST VIRGINIA, DECEMBER, 1967

\begin{tabular}{lccc}
\hline \hline \multicolumn{1}{c}{ Type of Ownership } & No. & \% of Total & $\%$ of Volume \\
\hline Single Proprietorship & 8 & 26.7 & 4.6 \\
Partnership & 3 & 10.0 & .4 \\
Profit-Type Corporation & 16 & 53.3 & 89.8 \\
Cooperative & 3 & 10.0 & 5.2 \\
\hline \multicolumn{1}{c}{ TOTAL } & 30 & 100.0 & 100.0 \\
\hline
\end{tabular}

ancludes both proces or-distributors and producer-processors 
TABLE 7

DISTRIBUTION of FLUID MILK PLANTS ${ }^{a}$ by ESTIMATED ANNUAL VOLUME and TYPE of OWNERSHIP, WEST VIRGINIA, DECEMBER 31, 1967

ancludes producer-processors 


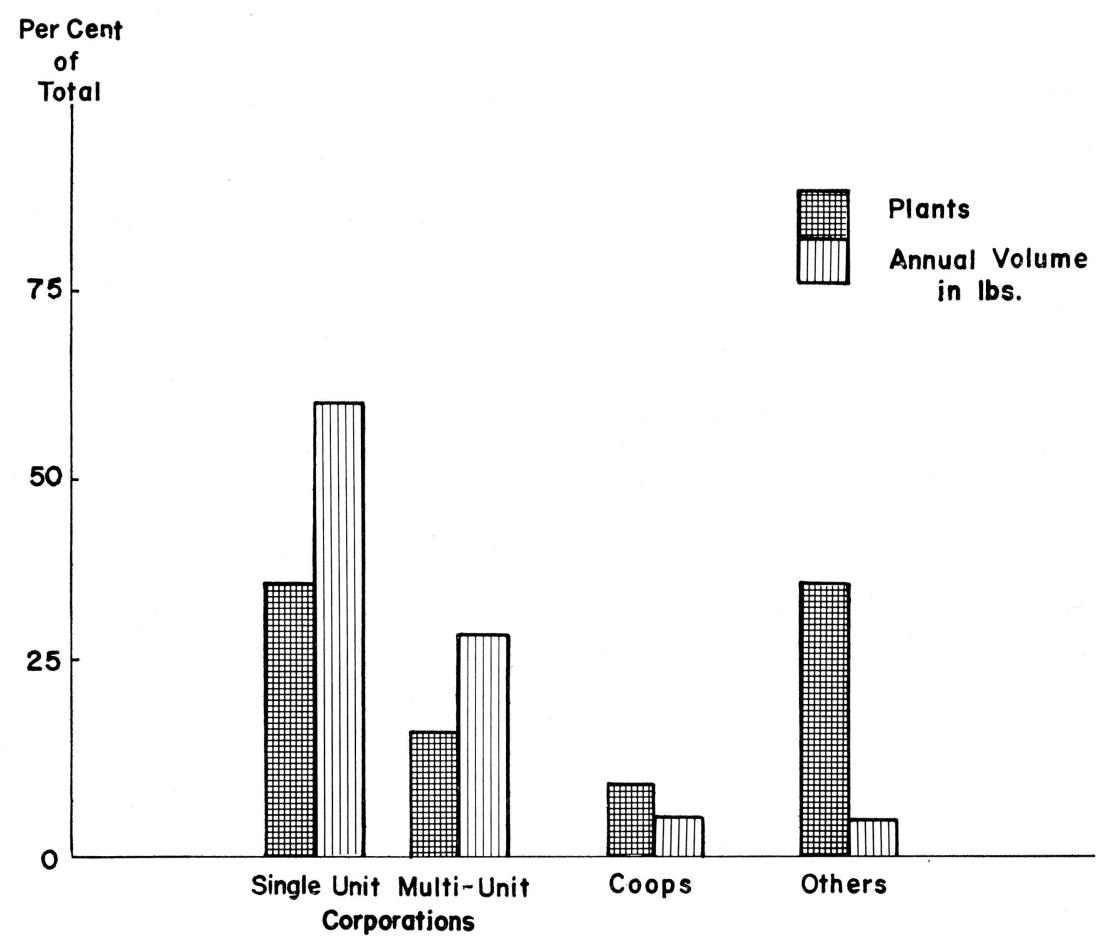

FIGURE 2. Fluid milk plants and annual volume, West Virginia, $196 \%$.

owned by profit-type corporations, with one half being owned by national dairy firms.

\section{Merger Activity}

Many of the firms that have increased their share of fluid milk sales in West Virginia markets have done so by means of external expansion. In most cases the expansion has been horizontal by means of merger-merger being defined as-"that kind of growth by which the business or facilities independent economic enterprises are brought under one control unit, either by purchase of one by the other or by a reorganization of the previously independent firms into one new enterprise."

There are several reasons why firms choose to expand by external means. These include economies of size, a desire for market power, and the broadening of the earning base.

${ }^{8}$ Hammond and Cook, op. cit., p. 6. 


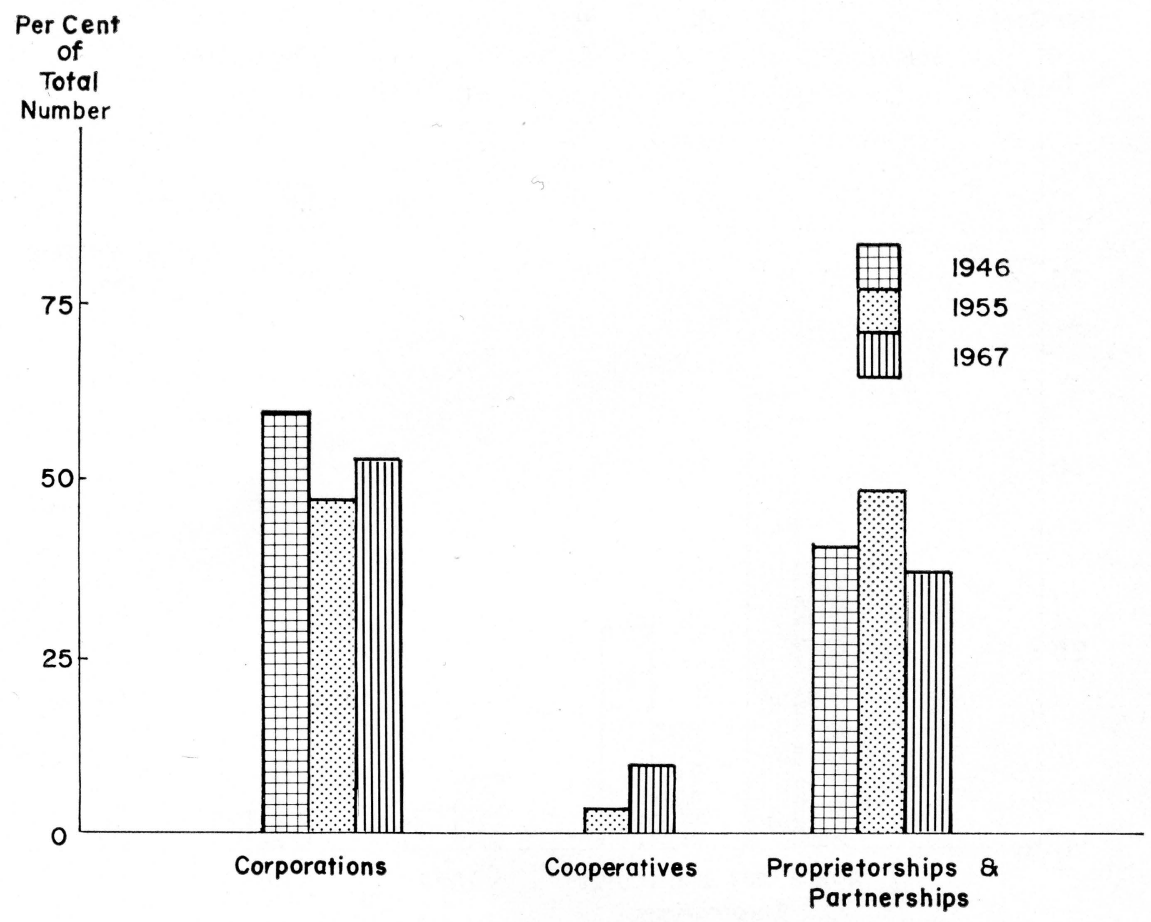

FIGURE 3. Proportion of fluid milk plants by type of ownership, West Virginia, 1946, 1955, and $196^{\circ \%}$.

Other reasons why firms choose to expand externally are: mergers are usually less expensive, there is usually less risk and uncertainity involved, and there are financing and tax advantages.

During the period 1946-1967, approximately 60 fluid milk plants in the State were acquired by other firms in and out of West Virginia (Table 8). In 19 of these cases only the routes (and goodwill) were purchased by the acquiring firm. Regional firms made 41.7 per cent of the acquisitions. Of the 25 acquisitions made by regional firms, 12 included only routes and goodwill.

Approximately 23.3 per cent of all acquisitions between 1946-1967 were made by national dairy firms (Table 8). Three of the national firms that acquired plants in West Virginia were ranked among the four largest companies processing dairy products in the United States in 1954 and in $1964 .^{9}$ All of the national concerns making acquisitions in the State between 1946-1967

${ }^{9}$ National Commission on Food Marketing, Technical Study No. 3, op. cit., p. 68. 
TABLE 8

NUMBER of ACQUISITIONS, by NATIONAL, REGIONAL and OTHER FIRMS, WEST VIRGINIA, 1946-1967

\begin{tabular}{|c|c|c|c|c|}
\hline Year & $\begin{array}{l}\text { National } \\
\text { Firms }\end{array}$ & $\begin{array}{l}\text { Regional } \\
\text { Firms }\end{array}$ & $\begin{array}{l}\text { Other } \\
\text { Firms }^{\mathrm{a}}\end{array}$ & Total \\
\hline 1946 & - & - & - & - \\
\hline 1947 & - & - & - & - \\
\hline 1948 & - & 2 & 1 & \\
\hline 1949 & - & - & - & \\
\hline 1950 & 1 & 2 & 1 & \\
\hline 1951 & - & - & 1 & 1 \\
\hline 1952 & 2 & 1 & 2 & 5 \\
\hline 1953 & - & 2 & 1 & 3 \\
\hline 1954 & - & - & 2 & 2 \\
\hline 1955 & 2 & 6 & 2 & 10 \\
\hline 1956 & - & 1 & 1 & 2 \\
\hline 1957 & - & - & 2 & 2 \\
\hline 1958 & 2 & - & - & 2 \\
\hline 1959 & 2 & 2 & 3 & 7 \\
\hline 1960 & 1 & 2 & 2 & 5 \\
\hline 1961 & 2 & 1 & 1 & 4 \\
\hline 1962 & 1 & 1 & - & 2 \\
\hline 1963 & - & 2 & - & 2 \\
\hline 1964 & 1 & - & 2 & 3 \\
\hline 1965 & - & 1 & - & 1 \\
\hline 1966 & - & 1 & - & 1 \\
\hline 1967 & - & 1 & - & 1 \\
\hline TOTAL & 14 & 25 & 21 & 60 \\
\hline
\end{tabular}

aProprietary, cooperative, or partnership

were among the eight largest dairy companies in the United States in 1954 and $1964 .^{10}$

Acquisitions have slowed down considerably in West Virginia during the last five years. Obviously, the number of firms which could merge has grown progressively smaller. Total or partial assets of only eight plants have been acquired by other firms since January 1, 1963. Five of these acquisitions involved only the purchase of routes and were made mostly by regional firms that had their processing facilities in a bordering state but were doing a large proportion of their business in West Virginia.

Only one acquisition has been made by a national firm since January 1, 1962, and this involved the purchase of routes of a small dairy plant.

${ }^{10} \mathrm{Ibi} \bar{a}$. 
Horizontal acquisitions, especially by national concerns, have been halted because of the institutional constraints placed on the largest eight dairy firms by the Federal Trade Commission (FTC). FTC has, since 1962, required two of the national firms to divest themselves of certain holdings in West Virginia. ${ }^{11}$

Merger activity prior to and during the period of this study has affected the structure of the fluid milk industry in West Virginia, both in the processing and distributing segments.

Based on the information available it is concluded that merger activity explains much and perhaps most of the increased share of total milk sales of the largest firms doing business in the State, and it played a prominent role in the rapid growth of independent firms that remain. Merger activity, however, has been encouraged by the necessity for expanding markets in order to achieve plant volume sufficient to reduce per unit processing costs when using paper cartons and larger processing equipment. These activities have been accompanied by improved merchandising, sales promotion, and sales contracts with large-volume buyers.

\section{Changes in the Method of Distribution}

Accompanying the decrease in numbers of fluid milk processing plants has been an increase in the number of plants dealing; wholly or predominately in the wholesale market, i.e., sales to retail food stores, restaurants, schools, and institutions. No data were available for years prior to 1967 on plants by type of trade. Two-thirds of the plants in 1967 sold milk on wholesale routes (Table 9). Only two plants, however, had sales which were 100 per cent wholesale. Plants that served some wholesale accounts and the two that were 100 per cent wholesale processed 96 per cent of the total volume of fluid milk processed in 1967 (Table 9).

Four of the 30 plants processing fluid milk in West Virginia in 1967 served only retail accounts, i.e., primarily households. Three of these plants were producer-processors and one was a producer-owned cooperative. Together they processed only 1.2 per cent of the total annual volume (Table 9). Six other firms sold more than 50 per cent of their volume directly to retail customers, but their share of the total market also remained at a low level (Table 9).

${ }^{11}$ Federal Trade Commission, Decisions, Findings, Orders and Stipulations, January 1 , 1962 - June 30, Vol. 60, (Washington: U. S. Government. Printing Office, 1963), p. 1048, and Docket No. 6653, op. cit., p. 221. 
TABLE 9

CHARACTERISTICS Of FLUID MILK PLANTS IN WEST VIRGINIA, DECEMBER 31, 1967

\begin{tabular}{lccc}
\hline \hline Characteristic & Number & $\begin{array}{c}\text { Per Cent of } \\
\text { Total }\end{array}$ & $\begin{array}{c}\text { Per Cent of } \\
\text { Volume }\end{array}$ \\
\hline Retail Only & 4 & 13.3 & 1.2 \\
Wholesale only $^{\text {Predominately Retail }}{ }^{\mathrm{a}}$ & 2 & 6.7 & 10.3 \\
Predominately Wholesale $^{\mathrm{b}}$ & 6 & 20.0 & 2.8 \\
\hline TOTAL & 18 & 60.0 & 85.7 \\
\hline
\end{tabular}

a Not including 100 per cent retail

bot including 100 per cent wholesale

A trend that has been generally apparent in the fluid milk industry was that the large firms have been concentrating on the wholesale trade and smaller firms have emphasized retailing.

The main reasons for specialization are: (1) the increased use of expensive, highly specialized equipment by the larger plants which necessitates high-volume production; (2) the decline in the number of retail food stores in West Virginia and the subsequent increase in size and in bargaining power of those remaining; (3) certain economies associated with specialization in distribution, i.e., reduced labor and truck costs and (4) the shift from home delivery to store buying and the local nature of home delivery which made this method of distribution more acceptable to small-scale operations.

Of the owners or managers of 30 fluid milk plants in West Virginia contacted in the fall of 1967,22 or 73.3 per cent replied that they were predominately retail when first established. Only one-third now deliver more than 50 per cent of their sales to the doorstep. Nine of the 10 plants that were either all or predominately retail had an annual volume of 2.2 million pounds or less. Further, five of these plants had a sales volume of less than 500,000 pounds in 1967 . Plants selling predominately to wholesale customers were by far the largest in the industry. Each of the 13 plants selling more than 50 per cent at wholesale-in most cases 70 per cent or more-processed more than five million pounds of milk in 1967 (Table 10). The four plants in the largest size category, those processing more than 20 million pounds annually, averaged selling approximately 78 per cent of their annual volume to supermarkets and various other wholesale outlets. 
TABLE 10

DISTRIBUTION of FLUID MILK PLANTS by ESTIMATED ANNUAL VOLUME and TYPE of TRADE, WEST VIRGINIA, DECEMBER 31, 1967

\begin{tabular}{|c|c|c|c|c|c|}
\hline \multirow{2}{*}{$\begin{array}{l}\text { Size of Plant } \\
\text { Annual Volume } \\
\text { (million lb.) }\end{array}$} & \multicolumn{4}{|c|}{ Type of Trade } & \multirow[b]{2}{*}{ Total $^{\mathrm{a}}$} \\
\hline & $\begin{array}{c}\text { Retail } \\
\text { Only }\end{array}$ & $\begin{array}{c}\text { Wholesale } \\
\text { Only }\end{array}$ & $\begin{array}{c}\text { Predominately } \\
\text { Retail }\end{array}$ & $\begin{array}{c}\text { Predominately } \\
\text { Wholesale }\end{array}$ & \\
\hline Less than 1.0 & 3 & - & 4 & 2 & 9 \\
\hline 1.0 to 4.9 & 1 & 1 & 2 & 4 & 8 \\
\hline 5.0 to 9.9 & - & - & - & 4 & 4 \\
\hline 10.0 to 19.9 & - & - & - & 5 & 5 \\
\hline 20.0 and over & - & 1 & - & 3 & 4 \\
\hline TOTAL & 4 & 2 & 6 & 18 & 30 \\
\hline
\end{tabular}

aIncludes producer-processors 
RETAIL DELIVERY. Competition from retail food stores has forced plants in West Virginia to change certain practices in home delivery. In the first place, as previously mentioned, store prices are usually lower; and secondly, home delivery has become more expensive due to rising labor and transporation costs and because delivery costs per stop become higher as customers switch from home delivery to store buying.

As late as 1956, 46.6 per cent of the producer-distributors who had plants in the State operated their retail routes on a threeday-a-week basis. Another 34.5 per cent delivered to homes everyother-day. Every-other-day deliveries were typical in the Wheeling and Clarksburg-Morgantown areas while three-day-a-week deliveries were typical in the Parkersburg-Huntington and Charleston-Beckley areas (Table 11). No firms reported twice-weekly deliveries in 1956.

At the time this study was made, all processor-distributors and producer-processors that served retail accounts were doing so on a twice-weekly or three-day schedule. Eight plants, or 36.4 per cent, delivered on a three-day schedule. Three plants had changed to twice-a-week service completely while another nine or 40.9 per cent were "experimenting" with this method (Table 11). These nine firms reported operating their retail routes on a combination five-day schedule with one group of customers receiving deliveries three days a week and another group receiving deliveries two days a week. Two other firms stated that twice-weekly deliveries had been planned for the future as a "last ditch" effort to make home-delivery more profitable. As of December, 1967, all eight producer-processors were servicing retail customers three days per week. Fifteen of the 20 processor-distributors presently operating plants in the State and servicing retail accounts reported that their sales through retail delivery were decreasing. These 15 plants gave the following reasons for the decrease in the percentage of their sales through retail delivery:

1. Customers can buy milk cheaper in grocery stores.

2. Not emphasizing retail trade-willing to let small distributors have this business.

3. Competent delivery men are not available and union wages are too high.

Of the producer-processors, five of eight reported increasing sales at the retail level. These dealers attributed their success to the following conditions: 


\section{Condition}

The public prefers locally produced and processed milk over milk brought in from other areas. (Producer-Processors believe their milk to be of better quality.)

More emphasis placed on retail sales
Number Responding

5

1

Apparently, the small-volume dealers, especially those in the Parkersburg-Huntington Area, have a good retail market and are

TABLE 11

FREQUENCY of RETAIL DELIVERY, FLUID MILK PLANTS in WEST VIRGINIA, 1955-56 ${ }^{b}$ AND DECEMBER, 1967

\begin{tabular}{|c|c|c|c|c|c|c|c|c|}
\hline \multirow{2}{*}{$\begin{array}{c}\text { Market Area } \\
\text { and Year }\end{array}$} & \multicolumn{8}{|c|}{ Frequency of Delivery } \\
\hline & $\begin{array}{l}\text { Two } \\
\text { Day }\end{array}$ & $\begin{array}{l}\text { Three } \\
\text { Day }\end{array}$ & $\begin{array}{c}\text { Every } \\
\text { Other } \\
\text { Day }\end{array}$ & $\begin{array}{l}\text { Four } \\
\text { Day }\end{array}$ & $\begin{array}{l}\text { Five } \\
\text { Day }\end{array}$ & $\begin{array}{l}\text { Six } \\
\text { Day }\end{array}$ & $\begin{array}{l}\text { Combin- } \\
\text { ation }\end{array}$ & None \\
\hline & \multicolumn{8}{|c|}{ Number of Plants } \\
\hline \multicolumn{9}{|l|}{ Wheeling } \\
\hline $1955-56$ & - & 2 & 8 & - & - & - & - & 1 \\
\hline 1967 & - & - & - & - & - & - & 2 & - \\
\hline \multicolumn{9}{|l|}{ Clarksburg- } \\
\hline Morgantown & & & & & & & & \\
\hline $1955-1956$ & - & 3 & 5 & 2 & - & - & 2 & - \\
\hline 1967 & 2 & 1 & - & - & - & - & 3 & - \\
\hline \multicolumn{9}{|l|}{ Parkersburg- } \\
\hline Huntington & & & & & & & & \\
\hline $1955-1956$ & - & 7 & - & - & 1 & - & - & - \\
\hline 1967 & 1 & 2 & - & - & - & - & - & 1 \\
\hline \multicolumn{9}{|l|}{ Charleston- } \\
\hline \multicolumn{9}{|l|}{ Beckley } \\
\hline $1955-1956$ & - & 7 & 1 & - & - & - & - & 1 \\
\hline 1967 & - & 1 & - & - & - & - & 2 & 1 \\
\hline \multicolumn{9}{|l|}{ Secondary } \\
\hline \multicolumn{9}{|l|}{ Markets } \\
\hline $1955-1956$ & - & 8 & 6 & - & - & 1 & 3 & - \\
\hline 1967 & - & 4 & - & - & - & - & 2 & - \\
\hline \multicolumn{9}{|l|}{$1955-1956$} \\
\hline TOTAL & - & 27 & 20 & 2 & 1 & 1 & 5 & 2 \\
\hline 1967 ТОТАL & 3 & 8 & - & - & - & - & 9 & 2 \\
\hline
\end{tabular}

aDoes not include producer-processors

bSource of 1955-1956 data: Report of the West Virginia Governor's Milk Commission, Charleston, February 1, 1967 
willing to expand; however, most of them are not as concerned about the availability of retail customers as they are about the availability of competent labor. Three of the eight producer-processors stated that the only restriction they have to increased sales is that they are not in a position to pay competitive wages; therefore, competent labor for farm production, processing, and delivery cannot be hired. This, they state, will eventually mean the demise of the small-volume handler in West Virginia.

WHOLESALE DELIVERY. In 1956, 44 plants or 76 per cent operated wholesale deliveries generally on a six-day-a-week basis (Table 12). The remaining 14 plants in that year delivered to wholesale customers on three-day, every-other-day, seven-day, and combination schedules. No plants delivered on a four-day or five-day basis (Table 12).

The patterns of wholesale distribution have changed considerably since 1956 . Twenty-one of the 22 processor-distributors doing business at the time this study was made operated wholesale routes. Fifty per cent of these plants were delivering milk to wholesale accounts five days a week. Another 40.9 per cent reported no change in the frequency of wholesale delivery, i.e., they remained on the six-day-a-week schedule. One small firm in the Beckley-Charleston Area has lowered its delivery frequency to four days weekly. Five-day delivery was typical in the Charleston-Beckley market while six-day delivery was typical in the Parkersburg-Huntington market. In the other three markets, the frequency of wholesale delivery was divided between five and six days a week (Table 12).

Most of the costs incurred by handlers in the fluid milk industry have been delivery and selling costs. ${ }^{12}$ Analyses of the milk distribution business indicated that distribution costs make up approximately 50 per cent of the total operating cost. ${ }^{13}$ In a study of 80 fluid milk plants in this country, in sizes ranging from one million to 40 million quarts annually, it was discovered that 49 per cent of total operating expenses were incurred in selling and delivery. ${ }^{14}$ Thus, substantial savings can be realized by reducing the frequency of delivery. Apparently, many of the firms have realized the economies to be gained from less frequent

\footnotetext{
${ }^{12} \mathrm{~J}$. C. Barron and W. C. Butz, Distribution of Fluid Milk Through Resale Outlets Practices and Cosis, Argicultural Experiment Station, The Pennsylvania State University, Bulletin 723, (University Park, Pennsylvania: The Pennsylvania State University, 1965), p. 21 .

${ }^{\text {is Ibid. }}$

${ }^{14}$ D. D. MacPherson, Milk Distribution Operation, Marketing Economics Division, Economic Research Service, ERS-84, (Washington: USDA, 1962), p. 26.
} 
wholesale delivery because of the action taken by many of them. Until recent years firms were not in a position to make less frequent deliveries. With the advent of large wholesale outlets and fewer "mom and pop" stores, larger trucks equipped with better refrigeration equipment, and better highways plus specialized distributing systems, namely, retail or wholesale, but not both, handlers have found it economical to reduce the frequency of delivery to resale outlets.

Many have been able to bring about cost savings in distribution through delivery of large volumes from plant to stores not

TABLE 12

FREQUENCY of WHOLESALE DELIVERY, FLUID MILK PLANTS in WEST VIRGINIA, ${ }^{a}$ 1955-1956 ${ }^{b}$ and DECEMBER, 1967

\begin{tabular}{|c|c|c|c|c|c|c|c|c|c|}
\hline \multirow{2}{*}{$\begin{array}{l}\text { Market Area } \\
\text { and Year }\end{array}$} & \multicolumn{9}{|c|}{ Frequency of Delivery } \\
\hline & $\begin{array}{l}\text { Two } \\
\text { Day }\end{array}$ & $\begin{array}{l}\text { Three } \\
\text { Day }\end{array}$ & $\begin{array}{c}\text { Every } \\
\text { Other } \\
\text { Day }\end{array}$ & $\begin{array}{r}\text { Four } \\
\text { Day }\end{array}$ & $\begin{array}{l}\text { Five } \\
\text { Day }\end{array}$ & $\begin{array}{l}\text { Six } \\
\text { Day }\end{array}$ & $\begin{array}{c}\text { Seven } \\
\text { Day }\end{array}$ & $\begin{array}{l}\text { Combi- } \\
\text { nation }\end{array}$ & None \\
\hline & \multicolumn{9}{|c|}{ Number of Plants } \\
\hline \multicolumn{10}{|l|}{ Wheeling } \\
\hline $1955-1956$ & - & - & - & - & - & 9 & - & 2 & - \\
\hline 1967 & - & - & - & - & 1 & 1 & - & - & - \\
\hline \multicolumn{10}{|l|}{ Clarksburg- } \\
\hline $1955-1956$ & - & - & 2 & - & - & 5 & 2 & 3 & - \\
\hline 1967 & - & - & - & - & 3 & 2 & - & - & 1 \\
\hline \multicolumn{10}{|l|}{$\begin{array}{l}\text { Parkersburg- } \\
\text { Huntington }\end{array}$} \\
\hline $1955-1956$ & - & 1 & - & - & - & 6 & - & 1 & - \\
\hline 1967 & - & - & - & - & 1 & 3 & - & - & - \\
\hline \multicolumn{10}{|l|}{ Charleston- } \\
\hline \multicolumn{10}{|l|}{ Beckley } \\
\hline $1955-1956$ & - & - & - & - & - & 9 & - & - & - \\
\hline 1967 & - & - & - & 1 & 3 & - & - & - & - \\
\hline \multicolumn{10}{|l|}{ Secondary } \\
\hline \multicolumn{10}{|l|}{ Markets } \\
\hline $1955-1956$ & - & 1 & - & - & - & 15 & - & 2 & - \\
\hline 1967 & - & - & - & - & 3 & 3 & - & - & - \\
\hline \multicolumn{10}{|l|}{$1955-1956$} \\
\hline TOTAL & - & 2 & 2 & - & - & 44 & 2 & 8 & - \\
\hline 1967 TOTAL & - & - & - & 1 & 11 & 9 & - & - & 1 \\
\hline
\end{tabular}

aDoes not include producer-processors
bSource of 1955-1956 data: Report of the West Virginia Governor's Milk Commission, Charleston, February 1, 1957 
only by reducing the frequency of delivery but by coordinating delivery services as well.

DISTRIBUTION AREAS. In the fall of 1967 representatives of approximately two-thirds of the fluid milk plants in the State reported that they had increased their distribution areas in recent years. Half of those reporting an increase were smallvolume, producer-processors. Fifty-nine per cent of the processordistributors also reported that they had expanded their market areas.

The average maximum distribution distance traveled from plants located in the State was 56.1 miles. When considered by type of operation, processor-distributors delivered an average maximum distance of 69 miles from the plant while producerprocessors delivered an average maximum distance of only 20.4 miles from the plant.

The expansion of distribution areas has resulted from two significant developments in the dairy industry. The first was technology in processing and the second was the decline in the number and consequent increase in size of wholesale buying units.

Many firms have installed new high-volume processing equipment and facilities at high initial or fixed costs. In addition this equipment became obsolete sooner than the equipment it replaced therefore making it necessary to recover costs as quickly as possible. Thus, to approach the minimum-cost operation for such equipment, large volumes of fluid milk must be processed.

As wholesale buying units became larger, more pressure was put on plants to increase volume in order to compete for these large accounts.

With the advent of the paper package and improved refrigeration and with the development of larger trucks and improved highways, one feasible method of expansion was to expand the area of distribution.

Ten of the 13 processor-distributors who were able to expand their markets in recent years indicated a "desire to increase volume so that lower unit costs could be realized" as the main reason for expanding their sales distribution areas. In addition, the following reasons were given as contributing to the increase in sales areas:

1. Population shift and growth.

2. Other plants going out of business.

3. The acquisition of plants in other areas. 
The five fluid milk processing plants owned by the national firms as of December, 1967 have increased their distribution areas to an average maximum distance of 108.2 miles. The range in maximum distances was from 60 miles to 175 miles.

As expected, the distribution area for the smaller plants extended fewer miles than did the areas of larger plants. Thirteen of the 17 plants (including producer-processors) processing less than five million pounds of milk in 1967 had routes that extended less than 50 miles from the plant (Table 13). Of the nine plants that processed more than ten million pounds, eight were selling in areas 50 miles or more from the plant. Furthermore, six of these nine plants distributed in areas 100 or more miles from the plant. Plants in the largest size category delivered milk to maximum distances which averaged 109 miles from the plant.

\section{Exit and Entry}

An entry, as defined in this study, is a new legal decision-making entity or a new legal entity with new productive capacity which has entered the fluid milk processing industry. An exit is a decision-making unit which has left the industry.

Between 1946 and December, 1967, 58 plants entered and 85 plants exited from the fluid milk processing industry in West Virginia (Table 14).

A little over 50 per cent of the fluid milk plants that were operated sometime between 1946 and December, 1967 had entered during that period. Nearly 74 per cent of the total firms operating

TABLE 13

DISTRIBUTION of FLUID MILK PLANTS ${ }^{a}$ by ESTIMATED ANNUAL VOLUME and MAXIMUM DISTRIBUTION DISTANCE, WEST VIRGINIA, DECEMBER 31, 1967

\begin{tabular}{lccccc}
\hline \hline & \multicolumn{3}{c}{ Maximum Distribution Distance (Miles) } & \\
\cline { 2 - 5 } $\begin{array}{l}\text { Plant Size } \\
\begin{array}{l}\text { Annual Volume } \\
\text { (Million 1b.) }\end{array}\end{array}$ & $\mathbf{0 - 9}$ & $\mathbf{1 0 - 1 9}$ & $\mathbf{2 0 - 4 9}$ & $\begin{array}{c}\mathbf{5 0} \\
\text { and } \\
\text { Over }\end{array}$ & Total \\
\hline Less than 1.0 & - & $\mathbf{4}$ & $\mathbf{4}$ & $\mathbf{1}$ & $\mathbf{9}$ \\
1.0 to 4.9 & 2 & 2 & $\mathbf{1}$ & 3 & 8 \\
5.0 to 9.9 & - & - & 2 & 2 & 4 \\
10.0 to 19.9 & - & - & $\mathbf{1}$ & 4 & 5 \\
20.0 and over & - & - & - & 4 & 4 \\
\hline \multicolumn{1}{c}{ TOTAL } & 2 & 6 & 8 & 14 & 30 \\
\hline
\end{tabular}

ancludes producer-processors 
TABLE 14

CHANGES in PLANT NUMBERS ${ }^{a}$ by EXIT

and ENTRY, WEST VIRGINIA, 1946-1967

\begin{tabular}{lcc}
\hline \hline \multicolumn{1}{c}{ Items } & \multicolumn{2}{c}{ Plants } \\
\cline { 2 - 3 } & Number $^{\mathbf{b}}$ & Per Cent \\
\hline Plants in Business, 1946 & 57 & 49.6 \\
Plants Entering, 1946-1967 & 58 & 50.4 \\
\multicolumn{1}{c}{ TOTAL ACCOUNTED FOR } & 115 & 100.0 \\
Plants Exiting, 1946-1967 & 85 & 73.9 \\
Plants in Business, 1967 & 30 & 26.1 \\
\multicolumn{1}{c}{ TOTAL ACCOUNTED FOR } & 115 & 100.0 \\
\hline
\end{tabular}

aIncludes producer-processors

${ }^{b}$ All data as of December 31

during this period had exited from the industry in the years between 1946 and 1967.

METHOD OF EXIT. Plants exited by selling to or merging with a new firm, selling to a previously existing firm, or by closing the plant. Approximately 22 per cent of the plants that left the industry during the 1946-1967 interval did so by selling their distributing business to a previously existing dairy firm. The plant and/or equipment in most cases was not purchased by the same firm that purchased the distributing business. The departing plant, in turn, was closed, converted to another non-dairy use, or dismantled (Table 15). Twenty per cent of the plants were sold to a previously existing firm and the facilities were closed down completely. Plants that were not sold, but which were closed down or converted into distributing points, accounted for 15.3 per cent and 14.1 per cent of the terminating plants, respectively. Only 12.9 per cent of the plants sold to previously existing firms were continued in operation (Table 15).

Plants which have changed status in the industry were categorized and analyzed in another manner; namely, those which were closed, those that have become distributors only, or those that changed ownership and remained in operation for a period of time. This is basically the terminology used by Jarrett and French in a recent study. ${ }^{15}$

Their definitions were as follows: (1) closed plants - plants in which physical facilities were actually taken out of the dairy

${ }^{15}$ William A. Jarrett and Charles E. French, Changes in the Ownership of Indiana Fluid Milk Plants, 1946-1955, Purdue University Agricultural Experiment Station, Research Bulletin No. 745, (Lafayette, Indiana: Purdue University, 1962), p. 14. 
TABLE 15

NUMBER and PROPORTION of PLANTS LEAVING the WEST VIRGINIA FLUID MILK INDUSTRY, by TYPE of

EXIT，1946-DECEMBER，1967

\begin{tabular}{|c|c|c|}
\hline \multirow[b]{2}{*}{ Method of Exit } & \multicolumn{2}{|c|}{ Plants } \\
\hline & Number $^{a}$ & Per Cent \\
\hline $\begin{array}{l}\text { Sold only the distributing business to a } \\
\text { previously existing firm }\end{array}$ & 19 & 22.4 \\
\hline $\begin{array}{l}\text { Sold processing and distributing busines } \\
\text { to a previously existing firm-plant } \\
\text { closed }\end{array}$ & 17 & 20.0 \\
\hline $\begin{array}{l}\text { No sale involved-plant was closed or } \\
\text { dismantled }\end{array}$ & 13 & 15.3 \\
\hline $\begin{array}{l}\text { No sale involved-plant was converted } \\
\text { into a distributing point }\end{array}$ & 12 & 14.1 \\
\hline $\begin{array}{l}\text { Sold processing and distributing busine } \\
\text { to a previously existing firm-plant } \\
\text { remained in operation }\end{array}$ & 11 & 12.9 \\
\hline $\begin{array}{l}\text { Sold processing and distributing busines } \\
\text { to a new firm or merged to form a } \\
\text { business }\end{array}$ & 7 & 8.2 \\
\hline $\begin{array}{l}\text { Sold processing and distributing business } \\
\text { to a previously existing firm-plant } \\
\text { converted into a distributing point }\end{array}$ & 6 & 7.1 \\
\hline TOTAL & 85 & 100.0 \\
\hline
\end{tabular}

ancludes producer-processors

industry, (2) distributors - plants which had stopped processing and had become distributors of products for others, and (3) changed plants - plants which changed ownership but continued processing. ${ }^{16}$

In this study the "closed plants" category included those in which processing facilities were shut down but the building and storage equipment were used in the operation of a distributing point for the firm's own products processed at other locations. Up until 1955 entries had exceeded exits (Table 16). Among the factors causing an increase in the number of plants was the entry of producer-processors who had previously been raw milk producer-distributors. 
TABLE 16

NUMBER of PLANTS OPERATED bY DAIRY FIRMS in WEST VIRGINIA, 1946 TO 1967, INCLUDING EXITS and ENTRIES of FLUID MILK PROCESSING PLANTS

\begin{tabular}{|c|c|c|c|c|c|}
\hline Year $^{a}$ & Plants & Exits $^{b}$ & Entries & Net & Change \\
\hline 1946 & 57 & - & - & & - \\
\hline 1947 & 61 & - & 4 & & +4 \\
\hline 1948 & 61 & 4 & 4 & & - \\
\hline 1949 & 69 & - & 8 & & +8 \\
\hline 1950 & 68 & 6 & 5 & & -1 \\
\hline 1951 & 72 & - & 4 & & +4 \\
\hline 1952 & 67 & 8 & 3 & & -5 \\
\hline 1953 & 69 & 2 & 4 & & +2 \\
\hline 1954 & 73 & - & 4 & & +4 \\
\hline 1955 & 66 & 16 & 9 & & -7 \\
\hline 1956 & 64 & 3 & 1 & & -2 \\
\hline 1957 & 64 & 2 & 2 & & - \\
\hline 1958 & 62 & 2 & - & & -2 \\
\hline 1959 & 56 & 8 & 2 & & -6 \\
\hline 1960 & 49 & 8 & 1 & & -7 \\
\hline 1961 & 47 & 4 & 2 & & -2 \\
\hline 1962 & 44 & 4 & 1 & & -3 \\
\hline 1963 & 42 & 3 & 1 & & -2 \\
\hline 1964 & 38 & 5 & 1 & & -4 \\
\hline 1965 & 36 & 3 & 1 & & -2 \\
\hline 1966 & 35 & 1 & - & & -1 \\
\hline 1967 & 30 & 6 & 1 & & -5 \\
\hline \multicolumn{2}{|c|}{ TOTAL } & 85 & 58 & & \\
\hline
\end{tabular}

${ }^{a} A s$ of December 31

${ }^{b}$ Includes plants in which processing facilities were taken out of the dairy industry, either by closing the plant entirely or by converting plants into a distributing point

The greatest number of exits occurred in 1955 when 12 plants closed and four changed ownership status. Since then plants have left the industry at a rather variable rate (Table 17).

Between 1946 and December, 1967, 61 plants or 72 per cent of the total number leaving the industry were in the closed class. Nineteen plants or 22 per cent changed ownership status and five closed their processing operations and became distributors for other plants (Table 17).

Plants that became distributors for others had been in business, on the average, for a longer period of time than the plants which changed status in other ways (Table 18). These 
firms were small operations that processed less than one million pounds of milk a year. Three processed less than 700,000 pounds annually. Four of the five who decided to become distributors stated that they did so because of the introduction of the paper container into their market and because their sales at the retail level were declining. They stated that their volume did not justify converting to paper containers, therefore, they could not compete in the wholesale market. In order to remain in the dairy industry, they chose to distribute for others.

Plants in the "changed" class were in business an average of

TABLE 17

NUMBER of FLUID MILK PLANTS WHICH

CHANGED STATUS, WEST VIRGINIA, 1946-1967

\begin{tabular}{|c|c|c|c|c|}
\hline \multirow{3}{*}{ Year $^{\mathrm{a}}$} & \multicolumn{3}{|c|}{ Number of Plants That: } & \multirow{3}{*}{ Total } \\
\hline & \multicolumn{3}{|c|}{ Became } & \\
\hline & Closed $^{b}$ & Distributors & Changed & \\
\hline 1946 & - & - & - & - \\
\hline 1947 & - & - & - & - \\
\hline 1948 & 2 & - & 2 & 4 \\
\hline 1949 & - & - & - & - \\
\hline 1950 & 5 & - & 1 & 6 \\
\hline 1951 & - & - & - & - \\
\hline 1952 & 5 & - & 3 & 8 \\
\hline 1953 & 1 & - & 1 & 2 \\
\hline 1954 & - & - & - & - \\
\hline 1955 & 12 & - & 4 & 16 \\
\hline 1956 & 1 & 1 & 1 & 3 \\
\hline 1957 & 2 & - & - & 2 \\
\hline 1958 & 2 & - & - & 2 \\
\hline 1959 & 5 & - & 3 & 8 \\
\hline 1960 & 6 & 1 & 1 & 8 \\
\hline 1961 & 2 & - & 2 & 4 \\
\hline 1962 & 3 & 1 & - & 4 \\
\hline 1963 & 2 & 1 & - & 3 \\
\hline 1964 & 5 & - & - & 5 \\
\hline 1965 & 3 & - & - & 3 \\
\hline 1966 & 1 & - & - & 1 \\
\hline 1967 & 4 & 1 & 1 & 6 \\
\hline TOTAL & 61 & 5 & 19 & 85 \\
\hline
\end{tabular}

as of December 31

bIncludes plants in which processing facilities were shut down but remaining facilities were used as distributing points for own product processed in other plants 
17.6 years (Table 18). Included in this group were plants that were merged with national and regional firms and which were among the largest in the State at the time the sale or merger took place. Approximately one-third of those in this group left the industry because the owner or owners wanted to retire, or because of death.

Plants in the "closed" category had been in business an average of 13.4 years and all plants that changed status between 1946 and 1967 had been in business an average of 14.6 years, with a range in business life from two to 45 years (Table 18).

To determine if the variation in the average life among class type was significant, an analysis of variance test was made. The test indicated that there was no significant variation in the average life among class types.

REASONS FOR EXITING. Information was obtained by personal interview for 30 of the 85 plants that exited from the fluid milk industry in West Virginia between 1946 and December, 1967. When personnel previously associated with the plants were asked-"What do you consider the most important reason you sold your firm or went out of business?"-approximately 17 per cent said they left the industry because of reduced profit margins (Table 19). Equal numbers of plants exited because of financial problems and poor management, personal problems, or high labor costs and labor problems (Table 19). The remaining 13 plants were sold or closed because of the paper container, the lack of volume to obtain processing efficiencies, unfair competition, and health regulations and the Federal milk marketing orders (Table 19).

TABLE 18

RANGE and AVERAGE NUMBER of YEARS PLANTS ${ }^{\text {a }}$ WERE in BUSINESS at TIME of CHANGE, by TYPE of CHANGE, WEST VIRGINIA, 1946-1967

\begin{tabular}{lcc}
\hline \hline \multirow{2}{*}{ Type of Change } & \multicolumn{2}{c}{ Period Operated } \\
\cline { 2 - 3 } & $\begin{array}{c}\text { Range } \\
\text { Years }\end{array}$ & $\begin{array}{c}\text { Average } \\
\text { Years }\end{array}$ \\
\hline Changed Plants & 3 to 41 & 17.6 \\
Closed Plants & 2 to 45 & 13.4 \\
Became Distributors & 11 to 31 & 20.0 \\
\hline TOTAL PLANTS & 2 to 45 & 14.6 \\
\hline \multicolumn{1}{c}{ aIncludes producer-processors } & &
\end{tabular}

ancludes producer-processors 
The above were first responses to the question; however, 80 per cent responded with two or more reasons for leaving. Twelve or 40 per cent claimed that a combination of three or more factors caused their exit from the industry. In addition to the reasons given in Table 19, exits occurred because: the family (primarily sons of the operators) was not interested in continuing the business, had good cash offers, were afraid the market was going to be disrupted by the entrance of large firms, equipment and buildings were in poor condition, consolidation, and various personal problems.

Sixteen of the plants that departed had installed some type of paper packaging equipment prior to their exit; however, 69 per cent stated that the purchase of this equipment was not to gain economies but was a competitive move because other plants in the area were using the paper container.

SIZE OF PLANTS EXITING. Of the 30 plants leaving 14 were in the group processing less than one million pounds annually. Several of these processed less than 600,000 pounds annually (Table 20). One third of those exiting were in the onemillion to five-million-pound size category. Four of the six plants exiting that processed in excess of five million pounds of fluid milk annually were merged with or sold to large regional or national dairy firms.

Data for 30 plants entering the industry between 1946 and December, 1967 were available. If these data are representative of all the entrants, it appears that those plants departing from the industry were replaced with other plants which were smaller (Table 20). This difference and apparent subsequent growth of the entering plants was not sufficient, however, to reduce the average volume of plants in 1967 below the level prevailing in 1946. Only two plants entered the industry with an annual volume of ten million pounds or more and these were plants which merged with national firms. Other characteristics of selected plants entering and leaving the industry during the period under consideration are summarized in Table 20.

Firms which left the industry between 1946 and December, 1967 delivered a maximum distance ranging from eight to 100 miles from the plant with an average maximum delivery distance of 29.4 miles.

The largest proportion, approximately 47 per cent, of those exiting from the industry were local proprietary operations while about 37 per cent were partnerships. 
TABLE 19

PRIMARY REASONS for EXITS,

20 SELECTED WEST VIRGINIA FLUID

MILK PLANTS, 1946-1967 ${ }^{\text {a }}$

\begin{tabular}{lcc}
\hline \hline \multicolumn{1}{c}{ Reason Given } & $\begin{array}{c}\text { Number of } \\
\text { Times Reason } \\
\text { Given }\end{array}$ & $\begin{array}{c}\text { Per Cent of } \\
\text { Total }\end{array}$ \\
\hline $\begin{array}{l}\text { Reduced Margins } \\
\begin{array}{l}\text { Financial Problems and } \\
\quad \text { Poor Management }\end{array}\end{array}$ & 5 & 16.6 \\
$\begin{array}{l}\text { Personal Problems (Health } \\
\quad \text { Of Owner, Family, etc.) }\end{array}$ & 4 & 13.3 \\
$\begin{array}{l}\text { High Labor Costs and Labor } \\
\quad \text { Problems }\end{array}$ & 4 & 13.3 \\
Retirement & 4 & 13.3 \\
$\begin{array}{l}\text { Paper Package } \\
\text { Lack of Volume to Obtain } \\
\text { Processing Efficiencies }\end{array}$ & 3 & 10.0 \\
Unfair Competition & 2 & 6.7 \\
Health Regulations and \\
$\quad$ Federal Milk Marketing Orders
\end{tabular}

aIncludes producer-processors

LOCATION OF PLANTS. Data were compiled on the location of plants for the years 1950,1960, and 1967. These years were chosen for comparison because of the availability of census data. During the period 1950 to 1960 attrition was the greatest in towns with a population between 2,000 and 9,999 (Table 21). Towns with a population between 10,000 and 24,999 lost the next highest number of plants during the same period (Table 21). Towns with a population of less than 2,000 experienced the lowest attrition rate. It had been expected that the loss would be higher in this category than for towns with larger populations. A study published in 1962 and covering the period 1946-1955 showed that plants in Indiana located in towns with less than 2,500 people had a significantly higher attrition rate than those in larger cities. ${ }^{17}$

${ }^{17}$ Jarrett and French, op. cit., p. 5. 
TABLE 20

CHARACTERISTICS of PLANTS ENTERING and LEAVING the

FLUID MILK PROCESSING INDUSTRY, WEST VIRGINIA, 1946 TO DECEMBER, 1967

\begin{tabular}{|c|c|c|c|c|}
\hline \multicolumn{5}{|l|}{$\overline{\overline{\text { Characteristic }}}$} \\
\hline \multirow{2}{*}{$\begin{array}{l}\text { Plant Size } \\
\text { (Annual Vol. Million lbs.) }\end{array}$} & \multicolumn{2}{|c|}{ Plants Leaving ${ }^{a}$} & \multicolumn{2}{|c|}{ Plants Entering ${ }^{\mathrm{b}}$} \\
\hline & Number & Per Cent & Number & Per Cent \\
\hline Less than 1.0 & 14 & 46.7 & 21 & 70.0 \\
\hline 1.0 to 4.9 & 10 & 33.3 & 6 & 20.0 \\
\hline 5.0 to 9.9 & 2 & 6.7 & 1 & 3.3 \\
\hline 10.0 to 19.9 & 3 & 10.0 & 2 & 6.7 \\
\hline 20.0 and over & 1 & 3.3 & - & $\cdots$ \\
\hline Producer-Processors & 6 & 20.0 & 17 & 56.7 \\
\hline Predominately Wholesale & 13 & 43.3 & 9 & 30.0 \\
\hline Predominately Retail & 14 & 46.7 & 9 & 30.0 \\
\hline Retail Only & 3 & 10.0 & 9 & 30.0 \\
\hline Wholesale Only & - & - & 3 & 10.0 \\
\hline
\end{tabular}

${ }^{\mathrm{a}}$ For 30 selected firms leaving industry

bFor 30 selected firms entering industry

During the period 1960-1967 cities with populations over 50,000 had the highest plant mortality rate with 61.5 per cent decline in number of plants (Table 21). Towns with populations of 1,999 or less lost the next to highest proportion of plants. Cities in the largest size category also had the highest attrition rate for the entire period 1950-1967 with a decrease from 17 to five plants (Table 21).

Chi-square tests were made to determine if the attrition rate for the periods 1950-1960, 1960-1967, and 1950-1967 varied significantly among towns in the different size groups. These attrition rates were not significant at the 0.05 level. $^{18}$

\section{Institutional Environment in Which Changes Occurred}

HEALTH REGULATIONS. The 1939 edition of the United States Public Health Service Code formed the basis for controlling the quality of West Virginia's milk supply until September 16, 1954, when the State Board of Health adopted a new set of regulations. ${ }^{19}$ These latter regulations became effective on December 16,1954 , and for all practical purposes were an exact duplica-

${ }^{18}$ For the period 1950-1960, the computed chi-square was 1.0252 and the tabular value was 9.488. For 1960-1967 the computed chi-square was 1.7866 and the tabular value was 9.488, and for the period 1950-1967, the computed value was 2.4342 and the tubular value was 15.505 .

${ }^{19}$ West Virginia Department of Health, The Public Health Laws of West Virginia and a Manual of Regulations of the West Virginia Board of Health, (Charleston, West Virginia : West Virginia Department of Health, 1950), p. 212. 
TABLE 21

NUMBER $^{a}$ and PER CENT of FLUID MILK PLANTS by SELECTED TOWN SIZES, ${ }^{b}$ WEST VIRGINIA, 1950, 1960, and 1967

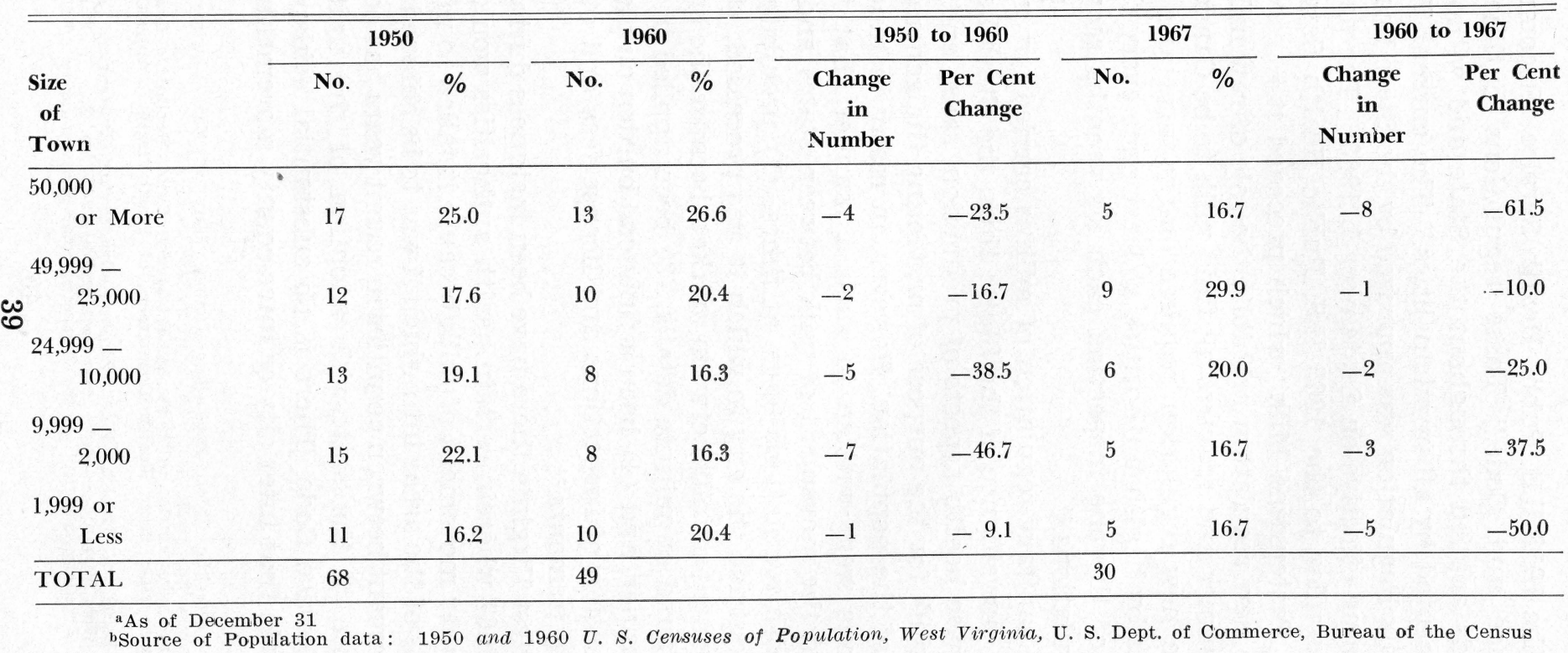


tion of the 1953 U.S. Public Health Service "Recommended Milk Ordinance and Code." These regulations outlined minimum standards applied throughout the State and without exception were accepted by all municipalities. ${ }^{20}$ The current West Virginia State Milk Regulation was approved by the State Board of Health and became effective on September $1,1968 .{ }^{21}$ The new regulation is very similar to the 1965 U.S. Public Health Service "Recommended Pasteurized Milk" which preceded it. ${ }^{22}$

The new regulation prohibits the sale of raw milk directly to the consumer and requires all fluid milk to be Grade $\mathrm{A}$. In addition, the new regulation requires on-the-farm and in-plant inspections by health authorities at least once every three months instead of the one inspection each six months required by the 1954 regulations. ${ }^{23}$

The sanitary regulation of milk is carried out under administrative surveillance of the State; thus, the State has the power to supervise health aspects of production, sales, and distribution of fluid milk for the purpose of protecting the general health and welfare of the population. However, in many instances, sanitary regulations were written in such a manner that they unduly restricted the movement of milk between states and municipalities. Health regulations have, at times, (1) prohibited milk from moving outside the city in which it was processed, (2) prevented the movement of milk between markets because the health regulations differed on minute details, (3) been applied in a discriminatory manner, and (4) been a financial burden on plants because of duplication of inspections and license fees and other burdensome requirements. ${ }^{24}$

In West Virginia there have been instances during the period 1946 to 1967 wherein certain health authorities would not permit inter-county movement of milk because it failed to meet with the standards of the areas into which it was to be shipped; but, generally movement between counties in recent years has occurred freely because of the state-wide adoption of the uniform Public Health Service Code. There is no substantial evidence available to conclude that inter-city or inter-county movement of milk has

\footnotetext{
${ }^{20}$ Letter from the Chief, Sanitation Section, State of West Virginia, Department of Health, February 26, 1968.

${ }^{21}$ Telephone conversation with Mr. A. H. Lively, Chief, Sanitation Section, Division of Sanitary Engineering, State Health Department of West Virginia, August 23, 1968.

${ }_{22}^{2}$ Ibid.

${ }^{23}$ State Board of Health, West Virginia Grade "A" Pasteurized Milk Regulation, (Charleston, West Virginia: State Board of Health, 1968), p. 8.

${ }^{24} \mathrm{USDA}$, Regulations Affecting the Movement and Merchandising of Milk, op. cit., 19.
} 
been impaired on the pretense of protecting health. It can be concluded, on the basis of the information available, that during the period of this study, the movement of milk into West Virginia from bordering states has been restricted. A suit by a Pennsylvania dairy firm to compel a county health officer in West Virginia to issue a permit to sell milk met with failure because the milk was not produced in conformance with the milk regulations of West Virginia. ${ }^{25}$ In other cases out-of-state firms, at times, have been unable to market milk in West Virginia because of the unwillingness of inspectors to inspect farms and plants out-of-state or because high inspection costs were incurred when out-of-state inspections were involved. ${ }^{26}$

At the time this study was completed, firms in Maryland, Virginia, Ohio, and Kentucky were issued permits by West Virginia authorities permitting shipment of milk into West Virginia as long as the shippers were on the Interstate Shippers List. Firms in Pennsylvania still were not able to market fluid milk in West Virginia because Pennsylvania's milk regulations were deemed not equivalent to those of West Virginia and the U.S. Public Health Service.

Firms with processing plants in West Virginia and desiring to sell out-of-state faced a different situation. As long as plants attained the milk sanitation compliance rating of the "Milk Ordinance and Code-1953 Recommendations of the Public Health Service" and were certified interstate milk shippers, they could sell milk in Ohio and Kentucky without trouble. There were barriers to the movement of milk into Maryland and Virginia. At the time this study was completed only four West Virginia firms were selling milk in these states. Three other plants in West Virginia on the Interstate Shippers List expressed a desire to market fluid milk in Maryland and Virginia, but plant representatives indicated they were denied permits for reportedly unknown reasons. Adequate information on the movement of milk from West Virginia into Pennsylvania was not available at this time but it is generally believed to be quite limited.

The extent to which sanitary regulations have changed the structure of the fluid milk industry in West Virginia is hard to quantify. Although West Virginia regulations were designed primarily for the improvement of the sanitary quality of milk, they

${ }^{25}$ Sleeth v. Dairy Products Company of Uniontown, 228 F. 2d, 165.

${ }_{20}^{2}$ Dairy Record, February 15, 1956, p. 8, June 22, 1960, p. 18, and March 7,1962 , p. 6 
have had significant effects upon the economic structure of fluid milk markets. Strict control of sanitation has improved milk quality thereby making it a more marketable product. This, in turn, has affected supply, demand, costs, and prices.

The general consensus of the owners or managers of the 30 fluid milk plants operating in West Virginia was that the regulations were seemingly becoming harder to comply with and required measures which were costly, both in the plant and on the farms. Such regulations nevertheless benefit the industry.

Representatives of only three plants expressed great dissatisfaction when questioned about sanitary regulations. This dissatisfaction resulted from the way they were being administered rather than from the provisions of the regulations themselves.

Of the 30 handlers who had left the industry during the period under study and who were interviewed, only one gave "sanitary problems" as the major reason for his departure from the industry. However, six other handlers stated that sanitary problems were secondary factors in causing them to leave the industry. Most of the plants exiting for this reason were small operations with poor equipment and facilities. They decided to close rather than to remodel facilities to meet sanitary requirements at the time of their exit.

The structure of the fluid milk industry has been changed in recent years by the failure of plants to make the Interstate Milk Shippers List. Twelve plants were distributing milk out-of-state at the time this study was made. Representatives of six of these plants stated that they were quite concerned about their status as certified interstate milk shippers. All six agreed that it was becoming more difficult to maintain a rating of 90 per cent or better on the basis of an official survey by the health department. The plants stand to lose a large portion of their business if taken off the Interstate Milk Shippers List.

That fewer and fewer firms are able to make the Interstate Shippers List because of strict State health inspections cannot be substantiated, however, the following information indicates a smaller percentage of processor-distributors on the list in 1968 than in 1963. On January 1, 1963, there were 22 fluid milk plants in West Virginia which were certified as having attained a sanitation compliance rating of 90 or better. ${ }^{27}$ At that time there were

${ }^{27}$ U. S. Department of Health, ENucation, and Welfare, Sanitation Compliance Ratings of Interstate Milk Shippers, Issue of January 1, 1963, (Washington: U. S. Public Health Service, 1963), pp. 36-37. 
37 processor-distributors operating fluid milk plants in the State, thus, approximately 60 per cent were certified interstate milk shippers.

When the list of interstate shippers on January 1, 1968, was published, ten of the 22 plants or 45 per cent of the processor-distributors were certified interstate milk shippers. ${ }^{28}$

FEDERAL MILK MARKETING ORDERS. The role of government in carrying out the procedures for developing and issuing Federal milk marketing orders is defined by the Agriculture Marketing Agreement Act of 1937, as amended, which authorized such programs. ${ }^{29}$ The responsibility of the U.S. Department of Agriculture is to judge the effect of the various proposals, to resolve problems presented in accordance with the standards prescribed in the Act and to enforce the orders after they are issued.

The principal mechanism included in a milk order was the statement of prices which handlers must pay producers for milk and the terms and conditions under which prices should be paid..$^{30}$

Representatives of 12 of the 19 regulated fluid milk plants in West Virginia stated that in their opinion Federal orders have created more stable and orderly marketing conditions and that a better "business" atmosphere has prevailed. Six stated that Federal orders have not helped the market and one made no comment.

Of the representatives of the 30 plants that exited from the industry, one said his firm left the industry primarily because of Federal orders. Three others said that the "red tape" of the order contributed to their decisions to leave the industry. ${ }^{31}$

\section{Changes in the Structure of the Buying Market}

Any study dealing with the structure of an industry should consider changes in the relationships among buyers and sellers since changes in the characteristics of either may result in changes in competitive behavior and performance.

In the fluid milk industry it is important to consider changes that have taken place in the market structure on the buying side, especially since the shift from home delivery to store buying and

${ }^{28}$ U. S. Department of Health, Education, and Welfare, Sanitation Compliance and Enforcement Ratings of Interstate Milk Shippers, Issue of January 1, 1968, (Cincinnati, Ohio: U. S. Public Health Service, 1968), p. 46.

${ }^{29}$ USDA, The Federal Order Program, Agricultural Marketing Service Bulletin No. 37. (Washington: U. S. Government Printing Office, 1963), p. 8.

${ }^{30}$ Ibid., p. 9.

${ }^{31} \mathrm{~A}$ comprehensive review of the coverage of West Virginia fluid milk markets by Federal orders is given in an unpublished master's thesis by Robert M. Bragg. Structural Changes in the West Virginia Fluid Milk Industry, 1946 to 1967, West Virginia University, 1969!, pp. 108-124. 
the growth of large supermarkets has resulted in the demise of many small-volume fluid milk handlers.

RETAIL BUYERS. There is no reason to believe that a change has occurred in the structure of the retail market in West Virginia, i.e., households who purchase milk through home delivery. Typically the retail market is atomistically structured, with each household being too small to have a significant effect on the market. In this case the buyers are "price takers" and therefore possess no market power.

WHOLESALE BUYING. In the decades between 1930 and 1950 buyers of fluid milk were the household consumers on retail routes; but, as related earlier in this study, the emphasis has shifted to store buying. The data presented in Table 22 concerning Federal order areas regulating a majority of the handlers in West Virginia show that for the relatively short period from November, 1963 to November, 1966 the percentage delivery to wholesale outlets increased in three of the four order areas. Therein lies a major problem facing the industry today. Outlets have changed from being atomistically structured to those which are oligopsonistic.

Occurrences in the food retailing industry have been very similar to those taking place in the fluid milk industry. The food industry has been characterized by declining store numbers, increasing store size, increasing concentration, and increasing integration and conglomeration of large chains.

TABLE 22

PROPORTION OF WHOLE MILK SOLD WHOLESALE and HOME DELIVERED, SELECTED FEDERAL MILK MARKETING AREAS,

NOVEMBER, 1963 AND NOVEMBER, 1966 ${ }^{a}$

\begin{tabular}{|c|c|c|c|c|}
\hline \multirow{3}{*}{$\begin{array}{l}\text { Federal } \\
\text { Market } \\
\text { Areas }\end{array}$} & \multicolumn{2}{|c|}{ Wholesale } & \multicolumn{2}{|c|}{ Retail } \\
\hline & 1963 & 1966 & 1963 & 1966 \\
\hline & \multicolumn{4}{|c|}{ (Per Cent) } \\
\hline Appalachian & 78.3 & 83.0 & 21.7 & 17.0 \\
\hline Clarksburg & 81.5 & 86.1 & 18.5 & 13.9 \\
\hline Tri-State & 79.4 & 83.6 & 20.6 & 14.4 \\
\hline Wheeling & 66.7 & 64.8 & 33.3 & 35.2 \\
\hline \multicolumn{5}{|c|}{ For 68 Selected } \\
\hline Markets & 70.6 & 72.0 & 29.4 & 28.0 \\
\hline
\end{tabular}


In 1954 there were an estimated 335,000 grocery stores in the United States, but the number of stores had declined to 227,000 by 1966 , or 32 per cent fewer stores. ${ }^{32}$ Most of the decline in store numbers between 1954 and 1966 was among small "mom and pop" stores while during the same period the number of stores affiliated with voluntary and cooperative independents increased.

During the same period the proportion of sales through chains, unaffiliated independents, and voluntary and cooperative independents was also changing. Groves reported the following sales data for the three types of stores in 1947, 1960, and $1966 .^{33}$

\begin{tabular}{|c|c|c|c|}
\hline \multirow[b]{2}{*}{ Type of Store } & \multicolumn{3}{|c|}{ Years } \\
\hline & 1947 & 1960 & 1966 \\
\hline & \multicolumn{3}{|c|}{ per cent of dollar sales } \\
\hline Chain & 37 & 39 & 41 \\
\hline Unaffiliated & & & \\
\hline Independents & 34 & 13 & 8 \\
\hline $\begin{array}{l}\text { Voluntary and } \\
\text { Cooperative }\end{array}$ & 29 & 40 & 51 \\
\hline
\end{tabular}

During the period 1954 to 1966 , average sales per grocery store in the United States increased from 104,000 to 311,000 dollars. $^{34}$ Growth patterns for the largest four, eight, and 20 grocery retailing firms in the United States are shown in Figure 4.

In 1954, the four largest grocery retailing firms controlled 45.4 per cent of the food retailing business within 218 standard metropolitan statistical areas in the United States. By 1958, the market shares of the four largest had increased to 49.3 per cent and to 50.1 per cent by $1963 .^{35}$

The trend in the number of retail food stores in West Virginia has been similar to the trend in the United States. Statistically, the changes have been as follows: From 1948 to 1963, retail food stores in West Virginia declined from 7,485 to 1,835 while during the same period average sales per store increased from

${ }^{32} \mathrm{~F}$. W. Groves, Vertical Integration in the Fluid Milk Industry, Department of Agricultural Economics, University of Wisconsin Staff Paper Series No. 21, (Madison: University of Wisconsin, 1968), p. 4.

${ }^{33}$ Ibid., p. 5.

${ }^{34}$ Ibid.

${ }^{35}$ National Commission on Food Marketing, organization and Competition in Food Retailing, Technical Study No. 7, (Washington: U.S. Government Printing Office, 1966), p. 43. 
$\$ 42,142$ to $\$ 229,525$ per year, an increase of 445 per cent (Table 23).

The extent of these changes in the retail food industry was reflected in measures of concentration. Data compiled for three standard metropolitan areas in West Virginia show the proportion of grocery store sales accounted for by the largest 20 grocery store companies increased from 58.4 in 1954 to 67.4 in 1958 and to 68.0 in 1963 (Table 24). During the 1954 to 1958 period, percentage

\section{Market}

Shares,

Per Cent

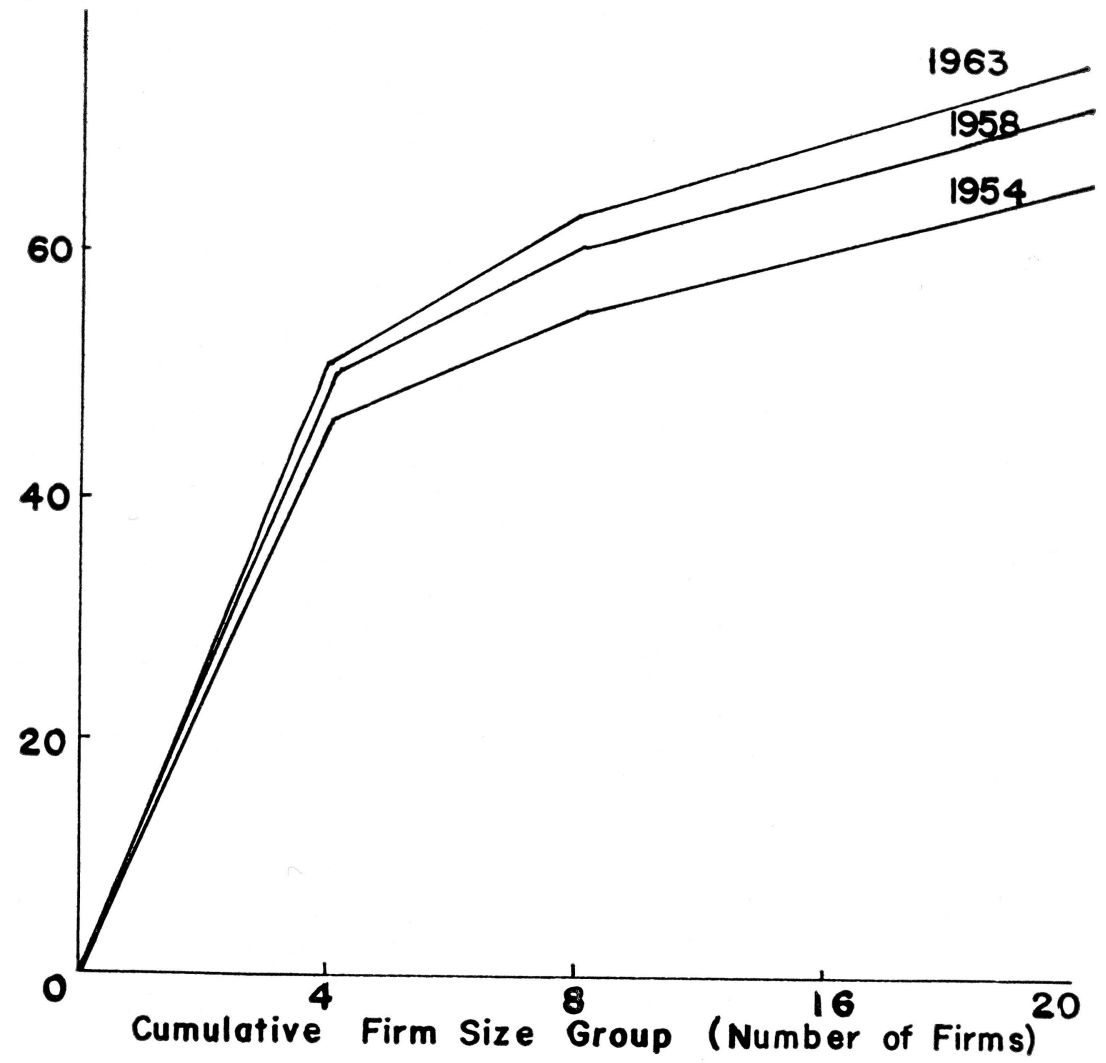

FIGURE 4. Concentration curves of the retail food industry in the United States, 20 largest firms in 218 standard metropolitan statistical areas, 1954, 1958, and 1963 (compiled from the National Commission on Food Marketing report, Organization and Competition in Food Retailing, Technical Study \%, pp. 4451). 
TABLE 23

NUMBER of RETAIL FOOD STORES and ANNUAL

SALES, WEST VIRGINIA, 1948, 1956, and 1963

\begin{tabular}{lccc}
\hline Year & $\begin{array}{c}\text { Number of } \\
\text { Establishments }\end{array}$ & Annual Sales & $\begin{array}{c}\text { Annual Sales } \\
\text { per Establishment }\end{array}$ \\
\hline $1948^{\mathrm{a}}$ & 7,485 & $\$ 315,433,000$ & $\$ 42,142$ \\
$1958^{\mathrm{b}}$ & 4,783 & $426,436,000$ & 89,157 \\
$1963^{\mathrm{c}}$ & 1,835 & $421,179,000$ & 229,525 \\
\hline
\end{tabular}

${ }^{a} U$. S. Census of Business, 1948, Vol. III, Retail Trade Area Statistics, U. S. Dept. of Commerce, Bureau of the Census, p. $7 \mathrm{~F}-503$

bVol. 1, Retail Trade - Summary Statistics 1958 Census of Business, p. 2-142

c1963 Census of Business, Retail-Wholesale Services, Vol. 1, Retail Trade Summary Stat., Part 4, Merchandise Line Sales, So. Atl. States and E. So. Atl. States, p. 47.02

shares of the largest four and eight companies increased overall, but between 1958 and 1963 the shares of these categories of companies declined from 54.3 to 50.7 and 60.3 to 58.6, respectively, for the three areas (Table 24). It is suspected that the decrease in market shares of the largest four and eight companies between 1958 and 1963 was a result of the growth of individual retailers who belonged to voluntary groups.

The market shares of the four, eight, and 20 largest food retailing companies are shown graphically in Figure 5.

It is important to note the significance of the shift from outlets which are atomistically structured to those which are oligopsonistically structured. Purchases are now in the hands of largevolume buyers who have tremendous market power. The existence of such large-volume buyers has created a need for fluid milk processing firms to increase plant size in order to provide the large volumes required by these outlets and to gain the scale necessary to bargain effectively with large-volume buyers.

\section{Private Labels}

Another change which has taken place in the retail food industry and which has had a significant impact on the structure of the fluid milk industry is the use of the private-label or store brands for dairy products.

Private-label brands or "distributor brands" have been used by supermarkets as a competitive device.

According to Cook:

Distributors develop brands for the same reasons as processors, to gain greater independence in establishing price and merchandising policies. When buying under his 


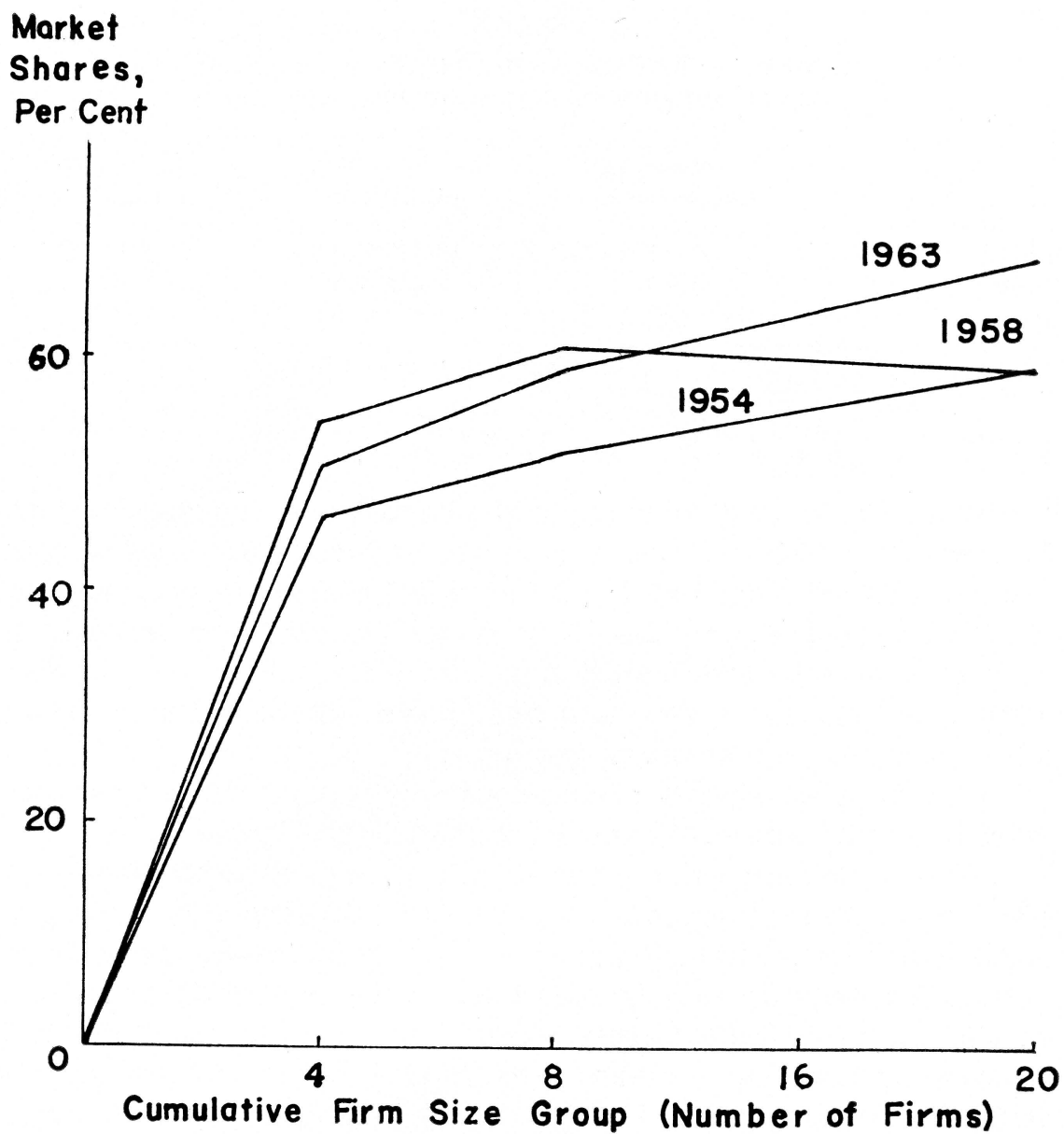

FIGURE 5. Concentration curves of the West Virginia retail food industry, 20 largest firms in three standard metropolitan areas, 1954, 1958, and 1963 (compiled from the National Commission on Food Marketing report, Organization and Competition in Food Retailing, Technical Study \%, pp. 44-51).

own brand, the distributor can afford greater indifference as to where he gets his supplies, and in selling such products he may adopt competitive strategies which give him a degree of independence from the price policies of retail competitors. ${ }^{36}$

${ }^{36}$ Hugh L. Cook, The Changing Market structure In the Dairy Industry-What Does It Mean? Talk given at Midwest Milk Marketing Conference, April 22, 1964, Minneapolis, Minnesota (Madison, Wisconsin: By the author, 1964), p. 10. 
TABLE 24

MARKET SHARES of LARGEST FOUR, EIGHT, and TWENTY GROCERY

COMPANIES, in THREE STANDARD METROPOLITAN AREAS in

WEST VIRGINIA, 1954, 1958, and 1963

\begin{tabular}{|c|c|c|c|c|c|c|c|c|c|}
\hline \multirow{3}{*}{$\begin{array}{c}\text { Metropolitan } \\
\text { Area }\end{array}$} & \multicolumn{9}{|c|}{ Percentage of grocery store sales accounted for by: } \\
\hline & \multicolumn{3}{|c|}{$\begin{array}{c}\text { Top } 4 \text { grocery } \\
\text { store companies }\end{array}$} & \multicolumn{3}{|c|}{$\begin{array}{r}\text { Top } 8 \text { grocery } \\
\text { store companies }\end{array}$} & \multicolumn{3}{|c|}{$\begin{array}{l}\text { Top } 20 \text { grocery } \\
\text { store companies }\end{array}$} \\
\hline & 1954 & 1958 & 1963 & 1954 & 1958 & 1963 & 1954 & 1958 & 1963 \\
\hline Charleston & 54.4 & 59.1 & 56.8 & 58.4 & 65.5 & 63.9 & 64.8 & 71.9 & 73.6 \\
\hline Huntington & 37.2 & 47.5 & 38.8 & 44.1 & 53.6 & 46.6 & 53.2 & 62.9 & 58.5 \\
\hline Wheeling & 46.6 & 56.4 & 56.6 & 52.6 & 61.9 & 65.2 & 57.1 & 67.4 & 72.0 \\
\hline AVERAGE & 46.1 & 54.3 & 50.7 & 51.7 & 60.3 & 58.6 & 58.4 & 67.4 & 68.0 \\
\hline
\end{tabular}

a Average of percentages shown for the three cities. Basic data for usual computation not available. 
In a study conducted by the National Commission on Food Marketing, the chain retail and wholesale groups were asked why they carried private-label products. The main reasons given were: (1) Private-label products permit us to develop consumer loyalty to a line of products carried exclusively in our store. (2) Our competitors stock private-label products and we feel it is necessary to carry private-label products to remain competitive. (3) We obtain a greater profit from private-label than from manufacturer's label product. ${ }^{37}$

Private-label brands are commonplace in West Virginia today. A large percentage of the supermarkets-whether they be chains or voluntary groups-have introduced private-label brands within the last five years. Information was collected on grocery store milk prices, types of containers in stores, dairy cabinet space allocations, and the extent of private labeling as this study was being made. Approximately 200 food stores were visited. Of this number, 71 carried private-label milk in containers of various sizes. Predominate among those carrying private-labeled milk were local stores of national chains.

In 40 of the 71 stores it was estimated that the private-label milk took up 80 per cent or more of the dairy case. In the Clarksburg-Morgantown market area approximately 30 per cent of the supermarkets dealing in private labeling carried only the store brand. The most common practice in supermarkets throughout the State was to carry the private-label and one other brand. In 19 instances, only the store's private label and the dealer brand of the firm packaging the private-label milk was in the dairy case.

In only one instance was the store price for fluid milk sold under the private-label brand higher than for the dealer's label, among the selected stores visited (Table 25). In four stores whole milk was sold in private-label half gallons and gallons at the same prices as in dealers' label containers.

For both half gallons and gallons the most common price difference was over six cents (Table 25). The price difference for gallons usually was greater than ten cents. Frequently the difference was greater than 15 cents per gallon.

There are various reasons why dairy firms supply privatelabel brands to supermarkets. Among those mentioned by the National Commission on Food Marketing were: (1) Ag-

\footnotetext{
${ }^{37}$ National Commisision of Food Marketing, Technical Study, No. 10, op. cit., p. 57.
} 
TABLE 25

STORE PRICE COMPARISONS BETWEEN PRIVATE-LABEL and DEALER

BRANDS FLUID MILK, WEST VIRGINIA, OCTOBER-DECEMBER, 1967

\begin{tabular}{|c|c|c|c|c|}
\hline \multirow{2}{*}{$\begin{array}{l}\text { Price Difference } \\
\text { (cents) }\end{array}$} & \multicolumn{2}{|c|}{ Half Gallons } & \multicolumn{2}{|c|}{ Gallons } \\
\hline & $\begin{array}{c}\text { Number of } \\
\text { Stores }\end{array}$ & Per Cent & $\begin{array}{l}\text { Number of } \\
\text { Stores }\end{array}$ & Per Cent \\
\hline Private Label Higher & 1 & 1.7 & - & - \\
\hline No Difference & 4 & 6.9 & 4 & 9.5 \\
\hline \multicolumn{5}{|l|}{ Private Label Lower: } \\
\hline 1.0 & 5 & 8.6 & - & - \\
\hline 2.0 & 9 & 15.5 & 1 & 2.4 \\
\hline 3.0 & 9 & 15.5 & 2 & 4.8 \\
\hline 4.0 & 6 & 10.4 & 3 & 7.1 \\
\hline 5.0 & 5 & 8.6 & 8 & 19.0 \\
\hline 6.0 & 9 & 15.5 & 6 & 14.3 \\
\hline Over 6.0 & 10 & 17.3 & 18 & 42.9 \\
\hline TOTAL & 58 & 100.0 & 42 & 100.0 \\
\hline
\end{tabular}

gressive independent dairy firms saw this as a means of getting new business and increasing their volume. (2) National dairy firms used this as a means to forestall the entry of chains and wholesalers into the processing of dairy products. (3) Large firms may sell under the retailer label with the idea that if they don't other firms will-this eventually will lead to lower profits. (4) Large firms started processing private label for food retailers in order to obtain and keep shelf space for their own brands. ${ }^{38}$

Five of the 30 fluid milk plants in West Virginia were engaged in processing private-label fluid milk as of December, 1967. These were the five largest plants in the State.

Prevalence of private-label brands indicates that large retail food stores are in a strong buying position in the market place, and that only the largest fluid milk processing firms are in a position to compete successfully for these large accounts.

\section{PART III}

\section{THE EFFECT OF THE CHANGING STRUCTURE ON MARKET CONDUCT AND PERFORMANCE}

In this part, an attempt will be made to determine the effect of the changes that have occurred in the structural variables discussed in Part II upon firm conduct and industry performance.

${ }^{38}$ National Commission on Food Marketing, Technical Study No. 3, op. cit., p. 144. 
Market conduct, in a general way, refers to the patterns of behavior which firms or plants follow in adapting or adjusting to the markets in which they operate. Economic theory suggests that these patterns of competitive behavior are largely determined by the market structure of the industry of which they are a member.

\section{The Effect of Change in Structure on Competitive Behavior}

In Part II it was concluded that the type of market structure existing in the fluid milk industry in West Virginia (when the entire State was considered one market) at the time of this study approximated that of a moderately concentrated oligopoly, i.e., a market structure of a small number of competitors. In this setting, rivals tend to behave in an interdependent manner. The oligopoly model may not adequately explain the situation that exists today as a result of the concentration that has occurred on the buying side, i.e., the growth of large supermarkets. ${ }^{1}$ Cook said regarding this oligopsony:

... by looking simultaneously on the buyer side, we find increasing competition. The shift in outlets to the chain stores and the ever increasing concentration among the chain outlets has resulted in a sort of "bilateral oligopoly." This situation may be quite different from what would be expected in looking solely at the structural characteristics on the seller side. ${ }^{2}$

The behavior of the oligopolistic fluid milk processing industry in the State would be expected to follow one of two policies, i.e., one that has been described by the phrase "live and let live" and the other by the phrase "dog eat dog." However with the existence of an oligopsonistic retail grocery group and its emerging interest in private-label milk, the behavior of the dairy group may have been influenced and price and output may be about the same as one would expect under pure competition.

Several practices firms usually follow in promoting a "live and let live" policy are discussed below.

PRICE FIXING. Price fixing directly violates both the Sherman Act and the Federal Trade Commission Act. Firms involved in price fixing may be taken to court by three parties, namely, the

\footnotetext{
${ }^{1}$ For detailed discussion on oligopoly theory and the concept of joint-profit maximization see William Fellner, Competition Among the Few, (New York: John Wiley and Sons, Inc., 1949), pp. 33-41, and Richard H. Leftwich, The Price System and Resource Allocation, (New York: Holt, Rinehart and Winston, 1965), Ch. 11.

${ }^{2}$ Cook, The Changing Market Structure in the Dairy Industry, op. cit., pp. 13-14.
} 
Antitrust Division of the Department of Justice, the Federal Trade Commission, and by private parties. ${ }^{3}$

The National Commission on Food Marketing in June, 1966 reported that of all price fixing cases brought to trial in the United States by antitrust agencies, the largest portion were cases involving milk and dairy products. ${ }^{4}$ This large percentage was attributed to the geographical size and resulting high degree of concentration that exists in most fluid milk markets. ${ }^{5}$

During the period 1950-1965, 17 formal complaints were made against firms handling milk and dairy products in the United States. As of June, 1966, 11 of these resulted in formal findings of illegality or consent settlements. ${ }^{6}$

Not cited by the commission in its list of the 17 firms charged with price fixing ${ }^{7}$ is the action initiated by the Antitrust Division of the Department of Justice against seven fluid milk processing firms and a producer marketing cooperative located in the Charleston market. ${ }^{8}$ The defendants were charged in May, 1956 with violating the Sherman Antitrust Act, however, after a yearlong investigation the companies involved were acquitted of the charge of price fixing. No other formal complaints of price fixing involving fluid milk plants in West Virginia were issued during the period covered by this study.

PRICE LEADERSHIP. Firms in oligopolistic industries, such as the fluid milk processing industry, generally follow the practice of price leadership-an acceptable practice in the eyes of the law. The price at which most of the firms in the market offer to sell fluid milk is determined by adopting the price announced by one of their number. Usually the largest firm in the market will establish a price and initiate price changes. Smaller firms are likely to follow because they believe the larger firm is better equipped to establish a satisfactory price level and in the short run are obliged to follow the leader's price changes or lose sales and profits.

Approximately 50 per cent of the representatives of the 30 West Virginia fluid milk plants interviewed indicated that they followed the market leader and frequently changed prices under the guise "of meeting competition."

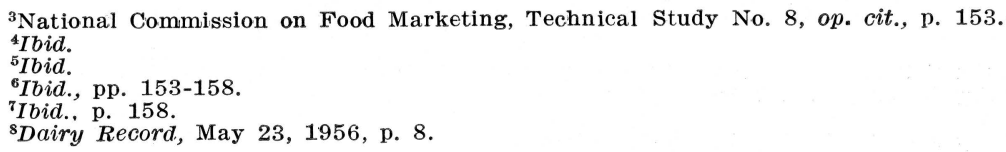


PRICE CUTTING AND DISCRIMINATION. Product differentiation in the form of private labeling was discussed in Part II. It was disclosed that a common practice in West Virginia markets was to offer private-label milk at a lower price. This practice has led to price cutting in many West Virginia markets or the introduction of secondary processor labels as retaliatory measures. Individual firms sometimes attempted to increase their share of the market through the practice of price discrimination.

During the period 1950-1965, the Federal Trade Commission brought several cases against firms in the dairy industry for price discrimination not justified by cost differentials. This practice has been held in violation of the Robinson-Patman Act. Eleven of the 17 formal complaints filed by the Federal Trade Commission against food manufacturing industries were in the dairy industry, while five out of six charges of price discrimination made by the Justice Department were in the dairy industry. ${ }^{9}$

Records indicated that only one formal complaint for this reason was filed by the FTC against a dairy firm operating a processing plant in West Virginia during the period of this study. The charge was brought by the FTC in July, 1965, and it was alleged that a national dairy concern violated the Robinson-Patman Act by selling milk and cottage cheese to three large chains at a lower price than it sold to the chains' supermarket competitors. ${ }^{10}$ The alleged discrimination took place in the Charleston market.

In the original complaint the FTC also charged one of the chains, a national concern, with violating Section $2(f)$ of the Robinson-Patman Act, i.e., it was charged with inducing and receiving lower prices than were charged other competitors, and that the company knew they were discriminatory in its favor. The complaint involved the pricing of private label products and was unusual in that charges were brought against both the buyer and seller. ${ }^{11}$

The hearing examiner recommended, in October, 1967, that the charges be dismissed; however, the dismissal was not final when this was written. ${ }^{12}$

\section{Performance of the Fluid Milk Processing Industry}

The assumption underlying this inquiry into the nature of market organization of the fluid milk industry in West Virginia

\footnotetext{
${ }^{9}$ National Commission on Food Marketing, Technical Study No. 8, op. cit., pp. 164-165.

${ }^{10}$ Dairy Record, August 18, 1965, p. 6.

${ }^{11}$ Ibid.

${ }^{12}$ Dairy Record, October 11, 1967, p. 6.
} 
is that the market structure and conduct of the firms in the industry influences the outcomes and results of market activity. This is to say, market structure determines market conduct which, in turn, determines market performance. In this study, the evaluation of performance factors will be limited to general discussion on levels of profit, costs, margins, and the progressiveness of firms in adopting technology and techniques of production. It is recognized that consideration of such a few factors is not sufficient to understand completely the performance of fluid milk markets in West Virginia. However, it must be understood that adequate data for such an undertaking were not available.

\section{Profit and Price Performance}

The profitability of firms is determined by the type of market structure in which they operate, i.e., the most influential variables are the degree of buyer and seller concentration, the conditions of entry, and the degree of product differentiation.

The fluid milk processing industry in West Virginia has become more concentrated, barriers to entry are relatively high and some effort has been made to differentiate packaged fluid milk. This leads to the tentative conclusion that competition in the industry has been lessened during the period covered by this study. This conclusion is based on studies done by researchers in the field of industrial organization. In the discussion on industry conduct, it was pointed out that in a situation where rivals are few, sellers tend to act in a manner which will maximize their profits. As seller concentration increases there is a corresponding tendency for industry profits to approach monopoly levels. It is a fact that seller concentration has increased substantially in West Virginia markets when only plants with processing facilities in the State are considered; however, in recent years more and more packaged milk has been shipped into West Virginia from several bordering states. This had tended to reduce sales concentration and thus it would be expected that industry profits would be lower.

Empirical studies testing the hypothesis that differences in market structures explain differences in profit rates have been difficult to conduct due to the non-availability of data for this purpose.

The National Commission on Food Marketing designed a study, using data obtained from 85 large companies, to test the 
above hypothesis. The Commission concluded:

Analysis of market structure of markets occupied by large food manufacturers showed a close positive statistical association between the level of market concentration and profit rates. That is to say, firms selling in highly concentrated markets earned substantially higher profit rates than those selling in less concentrated markets. ${ }^{13}$

The Commission concluded that profits in industries in which the concentration ratios of the top four firms in the dairy industry ranged from 35-50 per cent were less than one-half those earned by moderately concentrated oligopolies (50-65 per cent), and just over one-third those earned by highly concentrated oligopolies (75 per cent and over).$^{14}$

INDUSTRY PROFITS. The Commission reported that in 1964 the net profit as a per cent of sales on fluid milk for 11 major dairy companies was 1.0 per cent or more. ${ }^{15}$ Also reported were data concerning the earnings of 70 proprietary firms (location unknown) in the early months of 1964 . The Commission reported that the net profit after taxes as a per cent of sales for the 70 firms averaged 1.7 per cent. ${ }^{13}$

The profitability of fluid milk processing firms in the United States for 1958-1961 is shown in Table 26. These data were compiled by the National Commission on Food Marketing from records of the Internal Revenue Service. During the period covered by the data, firms with assets under $\$ 50,000$ had negative profits in the aggregate and in 1959 and 1960 firms with assets under $\$ 99,000$ had negative profits when considered in the aggregate. The profit after income taxes for all firms remained stable for the four-year period (Table 26).

More recent data (1964) show that profits for half-gallon containers for the fluid milk operation of 70 firms averaged a little over 1.5 per cent. ${ }^{17}$ This suggests that perhaps profits had declined somewhat between 1961 and 1964; however, the data for 1961 included the profits of the firm and the 1964 data included the profits on a specific product and are not altogether comparable. The data presented above are for selected firms throughout the

\footnotetext{
${ }^{13}$ National Commission on Food Marketing, Technical Study No. 8, op. cit., p. 212. A discussion on the technique used in the analysis may be found on pp. 203-207.

${ }^{14}$ Ibid., p. 207.

${ }^{15}$ National Commission on Food Marketing, Technical Study No. 3, op. cit., p. 203.

${ }^{16}$ Ibia.

${ }^{17}$ National Commission on Food Marketing, Cost Components of Farm-Retail Price spreads for Foods, Technical Study No. 9, (Washington: U.S. Government Printing Office, 1966), pp. 37-38.
} 
TABLE 26

PROFIT AFTER INCOME TAXES as A PER CENT of BUSINESS RECEIPTS and as a PER CENT of NET WORTH, FLUID MILK PROGESSING FIRMS, by SIZE GROUPS, 1958-61 ${ }^{\mathrm{a}}$

\begin{tabular}{|c|c|c|c|c|c|c|c|c|c|c|c|}
\hline \multicolumn{12}{|c|}{ Total Assets (thousands of dollars) } \\
\hline Year & $\begin{array}{c}\text { Under } \\
50\end{array}$ & $\begin{array}{c}50 \\
\text { to } \\
99\end{array}$ & $\begin{array}{r}100 \\
\text { to } \\
499\end{array}$ & $\begin{array}{c}500 \\
\text { to } \\
999\end{array}$ & $\begin{array}{c}1,000 \\
\text { to } \\
4,999\end{array}$ & $\begin{array}{c}5,000 \\
\text { to } \\
9,999\end{array}$ & $\begin{array}{c}10,000 \\
\text { to } \\
49,999\end{array}$ & $\begin{array}{c}50,000 \\
\text { to } \\
99,999\end{array}$ & $\begin{array}{c}100,000 \\
\text { to } \\
249,999\end{array}$ & $\begin{array}{c}250,000 \\
\text { or } \\
\text { more }\end{array}$ & $\begin{array}{c}\text { All } \\
\text { Firms }\end{array}$ \\
\hline \multicolumn{12}{|c|}{ Per Cent of Receipts } \\
\hline 1958 & -1.3 & 0.2 & 0.7 & 1.0 & 1.3 & 2.3 & 2.2 & 1.9 & 2.1 & 2.4 & 1.6 \\
\hline 1959 & -1.7 & -.2 & .7 & .9 & 1.3 & 1.5 & 2.6 & 1.8 & 2.1 & 2.5 & 1.6 \\
\hline 1960 & -2.0 & -.2 & .7 & 1.4 & 1.0 & 1.3 & 1.8 & 1.7 & 2.0 & 2.6 & 1.5 \\
\hline 1961 & -.1 & .5 & .6 & 1.0 & 1.0 & 1.5 & 1.6 & 1.6 & 2.1 & 2.7 & 1.6 \\
\hline \multicolumn{12}{|c|}{ Per Cent of Net Worth } \\
\hline 1958 & -12.9 & 1.2 & 4.7 & 5.8 & 7.0 & 8.8 & 8.7 & 7.8 & 10.0 & 8.6 & 7.6 \\
\hline 1959 & -26.1 & -1.4 & 4.1 & 6.4 & 6.9 & 7.0 & 7.4 & 7.4 & 9.3 & 9.1 & 7.5 \\
\hline 1960 & -55.2 & -1.7 & 5.4 & 7.9 & 5.5 & 5.6 & 6.3 & 5.3 & 8.9 & 9.4 & 7.3 \\
\hline 1961 & -1.2 & 4.1 & 4.2 & 5.8 & 5.8 & 6.1 & 6.3 & 5.4 & 9.4 & 9.1 & 7.3 \\
\hline
\end{tabular}

aSource: National
1966 , p. 204, Table $14-9$ 
United States and may or may not be representative of profits in the fluid milk processing industry in West Virginia.

MARGINS. An idea of how the West Virginia fluid milk industry has performed during the period of this study may be obtained from the data presented in Table 27.

TABLE 27

FLUID MLL: MARGINS PER HALF GALLON for EIGHT SELECTED MARKETS and the UNITED STATES, 1955, 1960, 1965, AND 1967 a

\begin{tabular}{|c|c|c|c|c|c|}
\hline Market & $\begin{array}{c}\text { Dealers' } \\
\text { Buying } \\
\text { Prices }^{b}\end{array}$ & $\begin{array}{c}\text { Wholesale } \\
\text { Margin }^{c}\end{array}$ & $\begin{array}{c}\text { Store } \\
\text { Margin }^{d}\end{array}$ & $\begin{array}{l}\text { Retail } \\
\text { Margin } \\
\text { (Sold in } \\
\text { stores) }\end{array}$ & $\begin{array}{c}\text { Retail } \\
\text { Margin } \\
\text { (Home } \\
\text { Delivered) }\end{array}$ \\
\hline
\end{tabular}

Charleston

$\begin{array}{llllll}1955 & 24.0 & 21.0 & 4.1 & 25.1 & 25.8 \\ 1960 & 25.1 & 26.5 & 3.2 & 29.7 & 28.3 \\ 1965 & 21.4 & 25.4 & 6.3 & 31.7 & 31.9 \\ 1967 & 25.3 & 24.4 & 3.6 & 28.0 & 26.9\end{array}$

Huntington

1955

1960

25.8

21.2

1965

1967

21.4

25.3

Wheeling

1955

1960

1965

1967

Pittsburgh"

1955

1960

1965

1967

25.4

17.1

28.3

24.7

21.9

19.6

23.1

21.1

21.7

27.6

27.4

23.1

26.1

Youngstown-

Warren

1955

1960

$1965^{\mathrm{h}}$

1967

Roanoke

$\begin{array}{ll}1955 & 29.2 \\ 1960 & 26.6 \\ 1965 & 27.2 \\ 1967 & 28.3\end{array}$

19.2

21.3

20.8

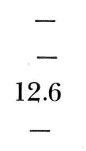

16.0

22.1

23.6

22.2
Cents

$\begin{array}{lll}5.1 & 22.2 & 22.4 \\ 5.8 & 34.1 & 32.0 \\ 5.0 & 29.7 & 22.1 \\ 4.7 & 26.6 & 20.9\end{array}$

$\begin{array}{rrr}5.7 & 25.3 & 26.0 \\ 4.7 & 27.8 & 26.7 \\ 3.5 & 24.6 & 23.7 \\ -1.3 & 20.4 & 21.6\end{array}$

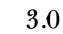

22.2

24.7

24.2

23.3

21.4

22.5

19.6

$-1.0$

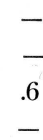

7.2
2.3
$-\quad .3$
-2.2

23.2

24.4

23.3

20.0

24.1

23.9

23.8

21.8 


\section{Lexington}

1955

20.4

13.2

10.1

23.3

24.9

1960

19.9

20.3

4.6

24.9

24.5

1965

20.3

18.7

2.8

21.6

20.8

1967

24.0

14.7

6.4

21.0

20.5

Knoxville

1955

22.8

21.1

5.3

26.4

26.4

1960

22.0

20.7

5.9

26.6

26.6

1965

18.9

23.5

1.7

25.2

27.1

17.1

3.0

20.1

20.1

Average of

W. Va. Markets

1955

25.7

19.2

5.0

24.2

24.7

1960

22.3

26.0

4.6

30.5

29.0

1965

21.2

23.7

4.9

28.5

25.9

1967

25.3

22.7

2.4

23.1

Average of

Other five

Markets

1955

25.0

17.3

5.6

23.8

25.0

1960

24.0

20.8

3.8

24.5

24.8

1965

22.2

19.9

1.0

26.2

28.4

1967

26.3

18.7

1.6

19.0

25.8

United States

1955

22.4

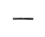

$-$

23.5

27.5

1960

21.9

$-$

$-$

25.0

29.0

21.3

$-$

21.7

26.6

1967

24.0

20.4

25.5

aPrices were adjusted using the wholesale and retail price indexes in the U. S. Department of Commerce Bureau of the Census, Statistical Abstract of the United States, 1967. Table No. 498, p. 349, 1957-1959=100

${ }^{b}$ Class I prices including negotiated premiums where reported. Adjusted to $3.5 \%$ butterfat and for plant shrinkage.

cThe difference between the price paid the farmer and the price received by the dairy plant from stores for milk in paper containers

dThe difference between the delivered price to the store and the price paid by the consumer at the store for milk in paper containers

The difference between the price paid the farmer and the store price paid by consumer for milk in paper containers

fThe difference between the price paid the farmer and the delivered price paid by the consumer for milk in glasis containers

gState regulated minimum prices to both dealers and consumers

hThree-month average

Source: USDA Agricultural Marketing Service, Fluid Milk and Cream Report, JanuaryDecember, 1955, Table 1; January-December, 1960, Table 1; January-December, 1965, Table 1; January-December, 1967, Tables 1 and 3 and Economic Research Service, Marketing and Transportation Situation, February, 1965, Table 8; February, 1966, Table 12 and February 1968, Table 19 
The data in this table were compiled from monthly issues of the Fluid Milk and Cream Report and selected issues of the Marketing and Transportation Situation. The margins were computed and deflated by using the United States indexes of wholesale and retail prices $(1956-59=100)$ to take into consideration the change in the purchasing power of the dollar. A more valid comparison could have been made if indexes of price levels for each region could have been obtained; however, such indexes were not available for the markets selected.

The prices paid to farmers, wholesale processor margins, and retail prices in the store and at home delivery in the three markets in West Virginia generally have been comparable with those in selected markets surrounding the State and in the United States (Table 27).

Retail cost, farm value, and marketing spreads for fluid milk changed little during the first half of the 1960's. Since 1965, farm prices have increased considerably while the farm-retail spread declined in most markets.

The average wholesale processor margin for the Charleston, Huntington, and Wheeling markets in West Virginia exceeded the average for the other five markets considered for all years given. The difference was 4.0 cents per half-gallon container in 1967.

National data are not available for comparison in 1967; however, when data released by the National Commission on Food Marketing for 1964 are compared with 1965 data for West Virginia markets and the other selected markets it was found that the wholesale processor margin in the latter markets exceeded the national margin.

The Commission released data for 70 firms operating througinout the United States. The average wholesale processor margin for these firms was 17.3 cents per half-gallon while in the West Virginia markets the margin for 1965 was 23.7 cents compared with 19.9 cents in the other five nearby markets (Table 27).

The above data suggest that (1) West Virginia firms in the aggregate either were operating more profitably per unit oi output or (2) they were operating less efficiently and thus had higher costs per unit of output than the aggregate of firms in the United States. However, because of a lack of cost data for West Virginia firms and the fact that the cost structure of fluid milk processing firms varied considerably from region to region, mainly due to the cost of labor, it was impossible to reach a conclusion as to which of these situations existed in West Virginia. 
The dealer's buying price for raw milk increased between 1960 and 1967 in all the markets studied and for the United States (Table 27). In comparing the increase in the West Virginia markets with that in the other five selected U.S. markets it was found that the price paid to the farmer increased from an average of 22.3 cents per half gallon equivalent in 1960 to 25.3 cents in 1967, or an increase of 13.5 per cent. The increase for the same period in the five selected markets and for the United States was 9.6 per cent. The level of farm prices was higher in the West Virginia markets than in the United States but lower than the average for the other five markets (Table 27).

While the dealer's buying prices increased between 1960 and 1967, the adjusted data show that wholesale processor margins and retail prices decreased (Table 27). Between 1960 and 1967, the average wholesale processor margin in the West Virginia markets decreased 12.7 per cent while the average in the other five markets declined 10.1 per cent. Similar data could not be obtained for the United States. Retail prices decreased in all markets during the same period but not as drastically as margins. ${ }^{18}$ The adjusted price data reveal that store prices for milk in paper containers in West Virginia decreased less than they did in the other selected markets while the decrease in adjusted prices for milk in glass containers on home-delivery routes was greater.

It is evident from the data presented that fluid milk firms were faced with rising costs on the one hand and a declining processing margin on the other, presumably due to the increased pressure from large buying units. Furthermore, the industry was unable to pass on very much of the increased costs to consumers in the form of higher prices. Thus, if reasonable profits were made, the increased cost must have been offset by technological efficiency, including innovation. This resulted in fewer and larger plants and wider distribution areas.

TECHNOLOGICAL PROGRESS. The major technological changes that were made in the West Virginia fluid milk industry during the period of this study include the state-wide acceptance of the paper container, the adoption of the bulk tank, and the shift to the continuous flow process in the plant.

Paper containers were used on a limited scale by a few plants

\footnotetext{
${ }^{18}$ Actual milk prices during much of this period were rising but they usually rose less rapidly than did either wholesale or consumer prices. Thus, adjusted prices for milk either rose less rapidly or fell relative to the prices of other products. The consumer price index rose more rapidly than did the wholesale price index, hence adjusted retail prices of milk often were relatively lower in 1967 than those existing in 1960.
} 
in West Virginia late in the 1940 decade. By the middle of the 1950 decade several plants had converted a portion of their operation to paper and by 1967, 20 of the 22 processor-distributors in the State were packaging in paper, however, only one-half of the firms packaged 75 per cent or more of their milk in paper. This should not be interpreted to mean that the firms in the State did not advance in this area as much as firms in other states. The plants packaging a smaller percentage of their milk in paper were doing so "to be competitive." In November, 1966, 68 per cent of the fluid milk sales in the four Federal order markets in West Virginia was packaged in paper containers. This is exactly the same percentage reported for 68 Federal order milk markets throughout the United States. ${ }^{19}$

The adoption of the paper container by West Virginia plants created the economic necessity to adopt other new technology in order to reduce costs.

Data collected from the 22 processor-distributors in operation at the time this study was completed revealed that the first bulk tank pick-up system was employed in the State in the very early 1950 's. The use of farm tanks has been adopted state-wide and by the fall of 1967,17 of the 22 plants had converted completely to the bulk receiving system.

The adoption of the bulk tank system served to lower plant costs and in many cases the operator reported receiving a higher quality of milk at the plant; however, the cost of conversion was great and meant the demise of many small-volume producers in the State as well as a good many small-volume plants.

The adoption of the paper container by West Virginia plants created the economic necessity to adopt other new techniques of pasteurization such as the continuous flow process of pasteurization using high temperatures, short-time (HTST) equipment and other new procedures. Seventy-seven per cent of the processordistributors had adopted HTST equipment by December, 1967.

Although fluid milk plants in West Virginia lagged behind plants in much of the Nation in adopting new technology, it is concluded that during the last eight to ten years the industry has advanced rapidly and that presently the industry in West Virginia compares favorably with that in other states as measured by the adoption of progressive techniques.

\footnotetext{
${ }^{19}$ Compiled from data presented in Packaged Fluid Milk Sales in Federal Milk Order Markets, Consumer and Marketing Service, CMS-11, (Washington: U. S. Department of Agriculture, 1966).
} 
EFFECTS ON THE PRODUCERS AND CONSUMERS. The returns to West Virginia farmers, in terms of the farmer's share of retail price, generally lagged behind the average share for United States farmers by about three per cent between 1955 and 1965 . Nevertheless, increases in the farm price since 1965 have been impressive and in 1967 the farmer's share of the retail store price for the three markets in West Virginia exceeded the national average by 1.9 percentage points.

When performance of the industry is considered from the consumers' point of view a brighter picture is apparent. In terms of constant dollars $(1957-1959=100)$, the price of fluid milk in stores by 1967 had decreased 4.7 per cent since 1955 in the three markets studied.

The introduction of the private-label into the fluid milk industry in the State has, at least for the time being, meant lower prices for consumers. Based on the data collected from grocery stores throughout the State in the fall of 1967 private-label brands in all but five cases sold at lower prices than processor labels. Inasmuch as regulations of production and processing of fluid milk results in a rather homogenous product, both brands are essentially the same product; thus, private-label milk represents a cost reduction for those consumers using it. In addition, data released by the National Dairy Council indicates that the "real" price of milk continues to decline relative to factory wage rates. In 1967, the average factory worker had to work only 12.2 minutes to earn enough to purchase a gallon of milk, whereas in 1947 the working time required was over 19 minutes, thus, indicating milk prices were rising at a slower rate than wage rates. ${ }^{20}$ This resulted in a lower "real" or comparative price for wage earners but consumers on fixed incomes did not similarly benefit because actual prices of milk have risen.

Cost data were not obtained for plants in West Virginia and therefore a breakdown of the processors' margins was not available for comparison with data for other markets. Nevertheless, it is concluded, based on the prices paid to farmers, that the fluid milk industry in the State is performing in a satisfactory manner and compares favorably with the industry in other areas of the United States. Although margins in West Virginia were approximately four cents per half gallon higher than in nearby markets, the processors in the State have adopted modern technological

\footnotetext{
${ }^{20}$ DCSA, Dairymen's Price Reporter, June, 1968, (Pittsburgh, Pa.: Dairymen's Cooperative Sales Assn., 1968), p. 16.
} 
processing innovations in an apparent effort to gain available efficiencies. Plant volume was lower in the State than the volumes customarily associated with lowest operating costs. Consumers, therefore, were paying somewhat more for milk than in most nearby markets, and from their standpoint market performance was not as satisfactory as for producers. Prices for them, however, had declined from previous levels. No information was available to measure plant profits, hence no conclusions can be drawn to indicate whether the industry is performing as well as it should under existing conditions.

\section{PART IV}

\section{SUMIMARY, CONCLUSIONS, AND IMPLICATIONS}

SUMMARY. The structure of the fluid milk industry in West Virginia changed considerably during the period 1946 to 1967. Since World War II the number of fluid milk plants has declined with an accompanying trend toward larger plants and increased concentration in the volume of fluid milk processed by the largest firms. The industry has also been faced with increased concentration on the buying side.

The problem of this study was to describe and analyze the structural changes which have taken place in the fluid milk industry in West Virginia and to appraise and evaluate the possible impact of these changes on processing firms, producers, and consumers.

The objectives of the study were: (1) to determine how and to what extent the structure and institutional framework of the fluid milk industry in West Virginia has changed during the post World War II period, (2) to determine the cause for the changes in the structure, especially the changing structure of food retailing and recent technological changes in fluid milk processing and distribution, (3) to investigate the effects of the change in structure on competitive behavior and industry performance, and (4) to determine the consequent effect of such changes upon producers and consumers. To fulfill these objectives inquiries were made into the changes that have occurred in the number and size of fluid milk plants, the changes that have occurred in buyer and seller concentration, the extent of exit from and entry into the industry, changes in the institutional framework, forms of competitive behavior and market performance as measured by mar- 
gins between prices received by producers and paid by consumers.

Primary data were collected by personal interviews with owners and/or managers of fluid milk plants located in West Virginia and in business at the time this study was made or with representatives of plants which have left the industry since World War II. From lists provided by the State Department of Agriculture, ic was determined that there were 30 plants in the first category and approximately 85 in the second. Questionnaires were completed for all plants in operation at the time the survey was made and for 30 plants which had left the industry during the period 1946 to 1967.

RESULTS. Data collected revealed that the number of fluid milk plants in West Virginia, both processor-distributors and producer-processors, increased from 57 in 1946 to a total of 73 as of December 31, 1954. Since that time, and up to December, 1967, the number of processor-distributors declined from 65 to 22 or 66 per cent but there has been no net change in the number of producer-processors.

Not considering producer-processors, plants processing less than 20 million pounds of fluid milk annually declined during the period 1956 to 1967 while plants processing 20 million pounds or more annually increased. In 1956 those plants with annual volumes of less than one million pounds processed approximately 3.9 per cent of the total volume, but by December 31,1967 , plants in this size category were processing only 0.3 per cent of the total volume processed in the State. Plants in the largest size group increased their share of the total volume processed from 12 per cent to 53 per cent during the same period. Average plant volume for processor-distributors increased 171.8 per cent between 1956 and 1967.

In 1956, the four largest firms' share of the total volume of milk processed in the State was approximately 40 per cent. By 1967, their share had increased to nearly 62 per cent, thus indicating that the largest firms play an important role in the industry. The shares of the largest eight, 12, and 16 firms also increased during the same period but not as much as did the share of the largest four.

Along with the decline in numbers of plants, there was a shift in the proportion of plants dealing primarily in wholesale trade relative to those dealing primarily in home delivery. Of the 30 fluid milk plants in business at the time this study was made, 22 
or 73.3 per cent stated that they were predominately retail when first established, however, only ten were dealing primarily in home delivery as of December 31, 1967. Nine of these ten plants had an annual volume of 2.2 million pounds or less. Plants selling predominately to wholesale customers were, by far, the largest in the industry. The four plants processing 20 million pounds or more annually averaged selling approximately 78 per cent of their annual volume to supermarkets and various other wholesale outlets.

Accompanying the increased emphasis toward wholesale delivery was a decrease in the frequency of delivery at both the retail and wholesale levels and an increase in the distribution areas of those plants remaining in the industry.

As late as 1956, 46.6 per cent of the producer-distributors operated their retail routes on a three-day-a-week basis. The remaining plants delivered more frequently. But by December 31, 1967, three plants had changed to twice-weekly home delivery completely while another nine, or 40.9 per cent, were experimenting with this method. None of the producer-processors reported making regular deliveries to homes more often than three times per week. The frequency of wholesale deliveries generally has changed from six days a week in 1956 to five days a week in 1967. Along with the reduction in delivery frequency there has been an increase in the maximum distance traveled from the plant in pursuit of wholesale accounts. Plants processing 20 million pounds or more at the time this study was made had a maximum delivery distance which averaged 109 miles from the plant. Three plants had routes extending 150 miles or more from the plant.

The study dealt, in considerable detail, with characteristics of plants that changed status in the industry between 1946 and 1967. Of the 85 plants that changed status, approximately 22 per cent left the industry by selling only their distributing businesses to a previously existing dairy firm. The next most popular method of exit was to sell the entire operation to a previously existing dairy firm which, in turn, closed the plant. Twenty per cent of the plants exited in this manner. Plants which changed status were classified in several ways. Tabulations by classes showed that 61 plants were closed, five stopped processing and became distributors for others, and 19 changed ownership but continued processing.

Interviews were conducted with 30 owners and/or managers 
of plants that had exited the industry since World War II. In response to the question, "What do you consider the most important reason you sold your firm or went out of business?" approximately 17 per cent said they left the industry because of reduced profit margins. Other reasons given for leaving included financial problems and poor management, personal problems, high labor costs and labor problems, and competitive forces related to the paper container.

Data were compiled on the location of plants for selected years. During the period 1950 to 1960 it was discovered that attrition was the greatest in towns with populations between 2,000 and 9,000; whereas, during the period 1960-1967, towns with populations over 50,000 had the highest plant mortality rate with a 61.5 per cent decline. Chi-square tests showed that the attrition rate for the periods 1950 to 1960,1960 to 1967 , and 1950 to 1967 did not vary significantly among towns in the different size categories.

Many of the fluid milk firms that increased their share of sales in West Virginia markets did so by means of merger. In the post-World War II period approximately 60 fluid milk plants in the State were acquired by other fluid milk firms. Most of the acquisitions (41.7 per cent) were made by regional firms, however, 14 or 23.3 per cent were made by national firms. Merger activity in the State slowed down considerably during the fiveyear period for 1963 to 1967 partially due to the constraints placed on the firms in the industry by the FTC and partially due to the fact that there were few plants left to merge.

The trend in the number of wholesale outlets for dairy products has been similar to trends for fluid milk plants, that is to say, they have become fewer and larger. From 1948 to 1963, the number of retail food stores in West Virginia declined from 7,485 to 1,835 while during the same period average sales per store increased from 42,142 to 229,525 dollars per year, an increase of 445 per cent. The market shares of the largest four, eight, and 20 grocery store companies in the State have also increased during the period of the study.

Large grocery stores in West Virginia have also adopted the private label or store brand for fluid milk in the last few years. Data were collected from 200 grocery stores in the fall of 1967. Of this number it was found that 71 stores carried private-label milk in containers of various sizes. Predominate among those carrying private-labeled milk were local stores of national chains. In about 
90 per cent of the stores visited, private-label milk was priced lower than the milk in the dealer's label.

As the market structure of the fluid milk industry has been changing so has the institutional framework in which the changes took place. Changes in the State's health regulations and in the Federal order system were considered the most important. Health regulations were difficult to comply with from time to time and no doubt contributed to the demise of several small plants in the State. During the period of this study statewide adoption of a uniform code based on the model prepared by the U.S. Public Health Service has resulted in fewer problems with regard to compliance. Because of the adoption of the uniform code by West Virginia and all but one of its neighboring states, barriers to inter-state movement of fluid milk have been reduced considerably.

Federal milk marketing orders have influenced structural changes in the industry. The first of these was the Tri-State Order which became effective August 1, 1945, and regulated the handling of milk within the corporate limits of Huntington and Parkersburg. Since that time, three other orders and numerous order amendments have become effective. The entire order system, at the time of this study, regulated 40 per cent of the State's geographical area wherein resided 74.5 per cent of the State's population.

The elements of market structure are considered to be related to competitive practices such as price fixing, price leadership, and price cutting and discrimination. The declining number of plants and the resulting increase in the proportion of sales made by a limited number of firms in the State suggest, at least from a theoretical standpoint, that the above practices are related to the oligopolistic market structure that now exists.

Records indicated that during the period of this study seven West Virginia firms were charged by the Justice Department with price fixing and one large firm was charged by the FTC for direct violation of the Robinson-Patman Act which prohibits price discrimination. In all cases the firms were acquitted. There were several incidents of "small-scale" price wars during the period 1946 to 1967, most of which were in the Charleston market.

Performance in the fluid milk industry in West Virginia is hard to measure due to the lack of data pertaining to costs of production and economies of size. One criterion of performance is the size of the marketing margin and its profit and cost com- 
ponents. Just how firms in West Virginia have profited was undeterminable from the data available, however, from various margins computed for three large markets in the State it appeared, at least superficially, that the industry's performance has been comparable with that in selected markets surrounding the State and in the United States.

Constant dollar prices paid the farmers in the three markets increased 13.5 per cent between 1960 and 1967 compared with a 9.6 per cent increase for the United States during the same period. In contrast, retail milk in stores in terms of constant dollars, continued to decrease.

Profits were uncertain but data collected revealed that the industry has performed satisfactorily in terms of adoption of new technology. Paper packaging equipment, continuous flow processing techniques, and bulk receiving systems have been adopted statewide and on a large scale.

CONCLUSIONS. Concentration among the fluid milk processing plants in West Virginia during the period 1946 to 1967 was rather dramatic. A larger share of the total volume of fluid milk pocessed in the State was controlled by a small number of larger firms.

The changing structure of the fluid milk industry resulted in elimination of a number of small-volume plants and firms. Pressure for greater plant volume brought on largely by advances in technology, especially the introduction of the paper carton and the continuous flow processing system, was attributed by plant representatives to be primarily responsible for the decline in the number of small fluid milk plants and the increase in large-scale plants. Furthermore, the shift from home delivery to store buying and the resulting necessity to gain volume enough to service large wholesale accounts contributed to the demise of smallvolume plants. Plants were forced to grow in order to survive, therefore, many were able to increase their volume through merger.

Changes in the structure of the buying market have affected the industry considerably. The food retailing industry became more concentrated in buying fluid milk during the period of this study; this resulted in a stronger competitive position for these buyers in the market place. A large proportion of packaged milk, as high as 86 per cent in the Clarksburg market during 1966, was sold through stores. The existence of such large-volume buyers 
has created a need in the fluid milk processing firms to increase plant size in order to provide the large volume required by these large-volume buyers. Large-volume independent grocery stores in the State also have adopted private label brands of fluid milk thus strengthening their competitive position as compared with chain grocery stores.

Performance of the industry, as indicated by various margins, indicated that the real prices received by farmers were increasing while wholesale processors' margins were decreasing and the real price paid for milk by the consumer was decreasing. Nevertheless, processing margins for West Virginia plants were higher than for plants in other selected nearby markets and for the aggregate of all United States markets. Without specific cost data, it was not possible to determine (1) profit level of West Virginia firms, or (2) their level of efficiency. A number of firms reported being squeezed out of the market by low profit margins. The smaller processing volume of West Virginia plants as compared with plants in other areas suggest that processing costs are likely higher in West Virginia than in many other areas. When performance was measured by the extent to which firms had adopted progressive techniques, it was concluded that West Virginia's fluid milk industry compares favorably with the industry in other states.

IMPLICATIONS. Competition will likely force more small plants out of the West Virginia fluid milk industry before plant numbers are stabilized. More specialized processing equipment has been and probably will be developed which will force plants to become larger and increase their distribution areas. Since the Clayton Act has placed constraints which prevent further concentration among many of the national and regional dairy concerns, especially those operating in West Virginia, it is expected that most of the growth will be among the larger independent firms.

It is anticipated that the retail grocery store industry will demand more private-label brands in the future, thus creating even more pressure on the remaining milk processing firms to increase plant size in order to meet the likely price competition and to supply the volume demanded by these large-volume buyers.

Firms will continue to specialize in either wholesaling or retailing. If it survives, milk delivery will be left to the small firm; thus leading the authors to conclude that not all small to 
medium-sized firms will be forced out of the industry in the immediate future.

Because of the nature of this study and limitations of empirical data, the smallest area in which structural characteristics were measured, in most cases, was within the geographical boundaries of the State of West Virginia. Greater insight concerning the impact of the changing structure could be obtained if individual markets could be studied in detail.

\section{BIBLIOGRAPHY}

\section{Books}

Bain, Joe S. Barriers to New Competition - Their Character and Consequences in Manufacturing Industries. Cambridge: Harvard University Press, 1956.

_____. Industrial Organization. New York: John Wiley and Sons, Inc., 1959.

Fellner, William. Competition Among the Few. New York: Alfred Knopf, 1949.

Fryer, H. C. Concepts and Methods of Experimental Statistics. Boston: Allyn and Bacon, Inc., 1966.

Galbraith, John Kenneth. American Capitalism. Rev. ed. Boston: Houghton Mifflin Company, 1956.

Leftwich, Richard H. The Price System and Resource Allocation. Third Editon. New York: Holt, Rinehart and Winston. 1965.

Market Structure Research - Theory and Practice in Agricultural Economics. Edited by Paul L. Farris, Ames, Iowa: Iowa State University Press, 1964.

Moore, John R., and Walsh, Richard G. Market Structure of Agricultural Industries Some Case Studies. Ames, Iowa: Iowa State University Press, 1966.

Papandreou, A. G. and Wheeler, J. T. Competition and Its Regulation. New York: Prentice-Hall, 1954.

Readings in Industrial Organization and Public Policy. Selected by a Committee of the American Economic Association. Homewood, Illinois: Richard D. Irwin, Inc. 1958.

\section{Bulletins}

Barron, J. C., and Butz, W. T. Distribution of Fluid Milk Through Resale Outlets Practices and Costs. Bulletin 723, University Park: Agricultural Experiment Station, The Pennsylvania State University, August, 1965.

Bartlett, Roland W. "A Preliminary Economic Analysis of the Federal Milk Order Program.” In Federal Order Markets - Some Problems and Suggested Changes. Bulletin No. 11, Urbana: Department of Agricultural Economics, University of Illinois, December, 1965.

--_-_, and Alexander, W. H. The Practice of Establishing Federal Order Marketing Areas as Related to Economic Theory. Bulletin No. AE 2957, Urbana: Department of Agricultural Economics, University of Illinois, August, 1953.

Baumer, E. F. "Home Delivery Revisited." In Milk Distribution and Packaging Trends in the Dairy Industry. Bulletin No. 13, Urbana: Department of Agricultural Economics, University of Illinois, January, 1967. 
Christensen, S. Kent. "Discussion - Prospects and Problems in Dairy Products Distribution in the Next Decade." Proceedings of Fifth National Symposium on Dairy Market Development. Chicago: Market Research Department, American Dairy Association, February 15-16, 1965.

Clarke, D. A. Jr. Economic Aspects of Government Milk Price Regulation. Bulletin 63-4, Berkeley: Agricultuxal Experiment Station, University of California, November, 1963.

Clarke, Jas. H., Haught, Adrian L. and Shaw, Charles N. Twice-Weekly Milk Delivery: Experience, Opinions and Economic Effects. Bulletin 525T, Morgantown: Agricultural Experiment Station, West Virginia University, June, 1966.

Cohn, Edward A., and Crutchfield, Lindon N. Ownership Changes Made By Bakery and Dairy Products Companies, 1959-1964. ERS 291, Washington: Economic Research Service, U. S. Department of Agriculture, June, 1966.

Cook, Hugh L. Paper Packaged Milk in Wisconsin - Its Part in Expanding Distribution Areas. Research Bulletin 179, Madison: Agricultural Experiment Station, Úniversity of Wisconsin, June, 1953.

___ - "The Purpose of Regulation and How Supply Control Can Be Handled." API Series 9, February, 1964. The Milk Industry in the Southeast. Published by the Agricultural Policy Institute. North Carolina State University, 1964.

Foelsch, Gertrude G., and Cook, Hugh L. An Analysis of Federal Court Decisions Relating to the Marketing of Fluid Milk. Research Bulletin 200, Madison: Agricultural Experiment Station, University of Wisconsin, January, 1957.

French, C. E. Indiana Independent Fluid Milk Companies. Research Report 115, Lafayette: Indiana Agricultural Experiment Station, Purdue University, August, 1964.

Hammond, Jerome W., and Cook, Hugh L. Wisconsin Dairy Firm Mergers: Extent, Causes, and Results. Research Bulletin 249, Madison: Agricultural Experiment Station, University of Wisconsin, June, 1964.

Harris, Edmond S. Classified Pricing of Milk: Some Theoretical Aspects. Technical Bulletin No. 1184, Washington: Marketing Research Division, Agricultural Marketing Service, U. S. Department of Agriculture, April, 1958.

Jarrett, William A., and French, Charles E. Changes in Ownership of Indiana Fluid Milk Plants, 1946-1955. Research Bulletin No. 745, Lafayette: Indiana Agricultural Experiment Station, Purdue University, May, 1962.

Krausz, N. G. P. “Trade Barriers on Milk." Papers in Dairy Marketing presented at the Agricultural Industries Forum, February 3, 1960. Published in Trade Barriers in Milk Distribution, Urbana: Department of Agricultural Economics, University of Illinois, June, 1960.

MacPherson, D. D. Milk Distributors' Operations - Analysis of Growth, Sales Distribution, Costs and Profits. ERS-84, Washington: Economic Research Service, Marketing Economics Division, U. S. Department of Agriculture, November, 1962.

Manchester, Alden C. Dairy Marketing. ERS-318, Reprint from Agricultural Markets in Change, Agricultural Economic Report 95, Washington: Economics Research Service, U. S. Department of Agriculture, October, 1966. 
Fluid Milk Markets - Number of Handlers and Market Shares, 1950-65. Statistical Bulletin No. 428, Washington: Economic Research Service, U. S. Department of Agriculture, June, 1968.

Moore, John R., and Clodius, Robert L. Market Structure and Competition in the Dairy Industry. Research Bulletin 233, Madison: Agricultural Experiment Station, University of Wisconsin, March, 1962.

Mueller, Willard F., and Garoian, Leon. Changes in the Market Structure of Grocery Retailing, 1940-58. Research Report 5, Madison: Agricultural Experiment Station, University of Wisconsin, April, 1960.

Padberg, Daniel I., and Clarke, D. A., Jr. Structural Changes in the California Fluid Milk Industry. Bulletin 802, Berkeley: Agricultural Experiment Station, University of California, June, 1964.

Reeves, James. "What Changes are Needed in Federal Milk Marketing Orders." In Federal Order Markets - Some Problems and Suggested Changes. Bulletin No. 11, Urbana: Department of Agricultural Economics, University of Illinois, December, 1965 .

Spencer, Leland. Development of the Federal Milk Order System as Related to N'ational Supplies and Surpluses of Milk, 1947-1963. A. E. Res. 162, Ithaca: Department of Agricultural Economics, Cornell University Agricultural Experiment Station, New York State College of Agriculture, January, 1965.

-_- and Christensen, S. Kent. Milk Control Programs of the Northeastern States. Part 2. Bulletin 918, Ithaca, New York: Cornell University Agricultural Experiment Station, November, 1955.

United States Department of Agriculture. Regulations Affecting the Movement and Merchandising of Milk. Marketing Research Report No. 98, Washington: Agricultural Marketing Service, June, 1955.

July, 1963 .

- - The Food Marketing Industries - Recent and Prospective Structural Changes. ERS-295, Washington: Economic Research Service, May, 1966.

Walsh, Richard G., and Evans, Bert M. Economics of Change in Marketing Structure, Conduct and Performance - The Baking Industry. New Series No. 28, University of Nebraska Studies, December, 1963.

Webster, Fred, Bradfield, Alec, Bowring, J. R., Moore, H. D. and Taylor K. A. Economies of Size in Fluid Milk Processing Plants. Bulletin 636, Burlington: Agricultural Experiment Station, University of Vermont, June, 1963.

\section{Mimeographs}

Cook, Hugh L. The Changing Market Structure in the Dairy Industry-What Does It Mean? Talk given at the Midwest Milk Marketing Conference, Minneapolis, Minnesota, April 22, 1964.

Freeman, Robert E. Expansion of Federal Milk Orders. A mimeograph summarizing a portion of the study "Marketing Areas and Related Issues in Federal Milk Orders," a Ph. D. thesis submitted to Purdue University, August, 1963. 
Helmberger, Peter. Factors Affecting Performance of the Agriculural Marketing System. Paper given at the Western Extension Marketing Training Conference, Salt Lake City, Utah, September 22, 1966.

Sosnick, Stephen. Operational Criteria for Evaluating Market Performance. Paper presented at the Market Structure Research Workshop, Purdue University, June 18-22, 1962.

United States Department of Agriculture. Milk in the Appalachian and Bluefield Marketing Areas. Agricultural Marketing Service, Mimeograph of hearings on the tentative marketing agreements and to the orders conducted at Bristol, Virginia on April 12-13, 1960, and Bluefield, West Virginia on April 14. 1960.

\section{Periodicals}

Babb, E. M. "How Significant is Size of a Federal Order Market Area," American Milk Review, Vol. XXVI, No. 10, October, 1964.

Bain, Joe S. "Relation of Profit Rate to Industry Concentration," Quarterly Journal of Economics, Vol. LXV, No. 3, August, 1951.

Clodius, Robert L., and Mueller, Willard F. "Market Structure Analysis as an Orientation for Research in Agricultural Economics," Journal of Farm Economics, Vol. XLIII, No. 3, August, 1961.

Cochrane, Willard W. "The Market as a Unit of Inquiry in Agricultural Economics Research," Journal of Farm Economics, Vol. XXXIX, No. 1, February, 1957.

Dairy Record, Vols. 55 to 68, St. Paul, Minnesota: The Dairy Record, 1955 to 1967.

Dairy Situation. DS-312, Washington: United States Department of Agriculture, Economic Research Service, September, 1966.

Fluid Milk and Cream Report. Washington: United States Department of Agriculture, Statistical Reporting Service, January to December, 1955, 1960, 1965 , and 1967.

Ghosh, Arabinda. "Market Structure Research: Comment," Journal of Farm Economics, Vol. 48, No. 1, August, 1966.

Marketing and Transportation Situation. Washington: United States Department of Agriculture, Economic Research Service, February, 1965, 1966, and 1968.

Nicoll, A. Olivia. “Milk Ordinance '65: What it Means," American Milk Review, Vol. XXVII, No. 4, April, 1965.

Sosnick, Stephen H. "A Critique of Workable Competition," The Quarterly Journal of Economics, Vol. LXXII, No. 3, August, 1958.

Williams, Sheldon W. "Private-Label Dairy Products in Food Stores," American Dairy Review, Vol. XXVIII, No. 6, June, 1966.

\section{Public Documents}

Federal Trade Commission, Decisions, Findings, Orders, and Stipulations, January 1, 1962 - June 30, 1962, Volume 60. Washington: United States Government Printing Office, 1963. 
- In the Matter of Beatrice Foods Company, A Corporation. Docket No. 6653, Initial Decision, March 2, 1964.

House Report No. 2565, Eighty-Seventh Congress, Second Session (1963) .

Market Administrator, Appalachian Milk Marketing Area. Compilation of Statistical Material Relative to Order No. 11, Appalachian Milk Marketing Area. April, 1968.

Market Administrator, Bluefield Milk Marketing Area. Statistical Material and Market Information, Bluefield Marketing Area, Federal Order No. 112 - 1960. Bristol, Tennessee.

Market Administrator, Clarksburg Milk Marketing Area. Annual Statistical Summary for the Clarksburg, West Virginia Marketing Area, Federal Milk Order No. 109-1960. Wheeling, May, 1961.

Annual Statistical Summary for Federal Milk Order No. 9 Regulating the Handling of Milk in the Clarksburg, West Virginia Marketing Area - 1967. Wheeling, January, 1968.

Market Administrator, Greater Wheeling Milk Marketing Area. Annual Statistical Summary for the Greater Wheeling, West Virginia Marketing Area, Federal Milk Order No. 102 - 1960. Wheeling, May, 1961.

-_-_- Annual Statistical Summary for Federal Milk Order No. 8 Regulating the Handling of Milk in the Greater Wheeling, West Virginia Marketing Area - 1967. Wheeling, January, 1968.

Market Administrator, Tri-State Milk Marketing Area. Compilation of Statistical Material Relative to Order No. 72 and the Tri-State Milk Marketing Area. January, 1955 .

- Annual Siatistical Summary for the Tri-State Milk Marketing Area, Federal Order No. 72, January 26, 1961.

-_-_- Annual Statistical Summary - 1967, Tri-State Marketing Area, Federal Order No. 5. Gallipolis, Ohio, January 12, 1968.

National Commission on Food Marketing. Cost Components of Farm-Retail Price Spreads for Foods. Technical Study No. 9, Washington: United States Government Printing Office, June, 1966.

Food from Farmer to Consumer. Washington: United States Government Printing Office, June, 1966.

. Organization and Competition in the Dairy Industry. Technical Study No. 3, Washington: United States Government Printing Office, June, 1966.

-____ Organization and Competition in Food Retailing. Technical Study No. 7, Washington: United States Government Printing Office, June, 1966.

-_-_-_. Special Studies in Food Marketing. Technical Study No. 10. Washington: United States Government Printing Office, June, 1966.

-____ The Structure of Food Manufacturing. Technical Study No. 8, Washington: United States Government Printing Office, June, 1966.

Sleeth v. Dairy Products Company of Uniontown, 228 F. 2d, 165.

United States Bureau of the Census. Census of Business, 1948, Volume III. Washington, 1950. 
-. Census of Business, 1958, Volume I. Washington, 1960.

- Census of Business, 1963, Volume I. Washington, 1965.

. Census of Population, 1950. Washington, 1952.

- Census of Population, 1960. Washington, 1961.

United States Department of Agriculture. Compilation of Statutes Relating to Marketing Activities, Including Research, Service, and Regulatory Work. Agricultural Handbook No. 130, Washington: United States Government Printing Office, 1958.

-_-_- Federal Milk Order Market Statistics. Consumer and Marketing Service, Statistical Bulletin No. 426. Washington, May, 1968.

- Packaged Fluid Milk Sales in Federal Milk Markets - By Size and Type of Container and Distribution Method. Consumer and Marketing Service. C \& MS -11 (Nov. 1963) and (Nov. 1966), Washington.

-_-_- Report to the Secretary of Agriculture by the Federal Milk Order Study Committee. Washington: United States Government Printing Office, April, 1962.

-_-_ Summary of Major Provisions in Federal Milk Marketing Orders. Consumer and Marketing Service. Washington, January 1, 1967 and January 1, 1968 issues.

United States Department of Health, Education, and Welfare. Sanitation Compliance Rating of Interstate Milk Shippers. Washington: Public Health Service. January 1, 1963.

-_-_. Sanitation Compliance and Enforcement Ratings of Interstate Milk Shippers. Cincinnati: Public Health Service, January 1, 1968.

United States Federal Register. Volume 10, Number 65, Washington, March 31, 1945. . Volume 20, Number 140, Washington, July 20, 1955.

West Virginia Department of Agriculture. Report of the West Virginia Governor's Milk Commission, Charleston, February 1, 1957.

West Virginia Department of Health. The Public Health Laws of West Virginia and a Manual of Regulation of the West Virginia Board of Health. Charleston, 1950.

West Virginia State Board of Health. West Virginia Grade "A" Pasteurized Milk Regulation. Charleston, September 1, 1968.

\section{Other Sources}

Cook, Hugh L. Economic Environment for Price Regulation in the Middle West. Staff Paper Series No. 8, Madison: Department of Agricultural Economics, University of Wisconsin, October, 1966.

Groves, F. W. Vertical Integration in the Fluid Milk Industry. Staff Paper Series No. 21, Madison: Department of Agricultural Economics, University of Wisconsin, March, 1968.

Handy, Charles Robert. A Critique of Traditional Market Performance Measures in the Food Industry. Unpublished paper.

Lively, A. L. Personal letter, February 26, 1968.

Rehberg, Wallace A. Market Structure Research as a Tool for Public Policy. Unpublished paper. Pullman: Department of Agricultural Economics, Washington State University. 
Blank Page in Original Bulletin 


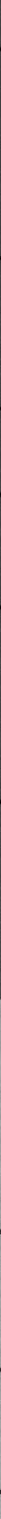

